\title{
Mitomycin Synthetic Studies: Stereocontrolled and Convergent Synthesis of a Fully Elaborated Aziridinomitosane
}

\author{
Robert S. Coleman,* François-Xavier Felpin, and Wei Chen \\ Department of Chemistry, The Ohio State University, 100 West $18^{\text {th }}$ Avenue \\ Columbus, Ohio 43210
}

\section{Supporting Information}

Contents:

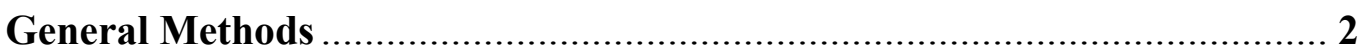

Experimental Procedures and Spectral Data ...................................... 2-22

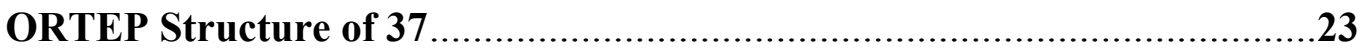

Nuclear Magnetic Resonance Spectra ............................................ 24-72 
General Methods: Proton and carbon NMR spectra were recorded on 400 and $500 \mathrm{MHz}$ spectrometers. Chemical shifts are reported in ppm relative to the chloroform peak at $7.24 \mathrm{ppm}$ $\left({ }^{1} \mathrm{H}\right)$ or $77.0 \mathrm{ppm}\left({ }^{13} \mathrm{C}\right)$, or the acetone peak at $2.04 \mathrm{ppm}\left({ }^{1} \mathrm{H}\right)$ or 29.8 and $206.0 \mathrm{ppm}\left({ }^{13} \mathrm{C}\right)$. Assignments in the ${ }^{1} \mathrm{H}$ NMR spectra were made using ${ }^{1} \mathrm{H}$ COSY and ${ }^{1} \mathrm{H} /{ }^{1} \mathrm{H}$ decoupling experiments. Mass spectroscopy was performed by the Ohio State University Chemistry Mass Spectrometry Facility using electrospray (ESI) or electron impact (EI) ionization. Infrared (IR) spectra were recorded on an FT-IR spectrometer as neat samples on $\mathrm{NaCl}$ plates. Unless otherwise specified, all reactions were run under an inert atmosphere of nitrogen. Solvents were freshly distilled before use. Yields refer to isolated material determined to be pure by NMR spectroscopy and thin layer chromatography (TLC), unless specified otherwise in the text.

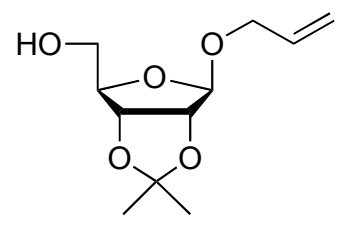

(6-Allyloxy-2,2-dimethyltetrahydrofuro[3,4-d][1,3]dioxol-4-yl)methanol (13). Concentrated $\mathrm{H}_{2} \mathrm{SO}_{4}(1.2 \mathrm{~mL})$ was slowly added to a solution of D-ribose (15.0 g, 100 $\mathrm{mmol})$ and allyl alcohol $(68 \mathrm{~mL})$ in acetone $(60 \mathrm{~mL})$ at $25^{\circ} \mathrm{C}$. The reaction mixture was stirred at reflux for $4 \mathrm{~h}$. The reaction mixture was allowed to cool to $25{ }^{\circ} \mathrm{C}$ and $\mathrm{Na}_{2} \mathrm{CO}_{3}(15.0 \mathrm{~g})$ was added. The mixture was filtered and the filtrate was evaporated in vacuo. The residue was diluted with $\mathrm{CH}_{2} \mathrm{Cl}_{2}(100 \mathrm{~mL})$ and washed with water $(70 \mathrm{~mL})$. The aqueous phase was extracted with $\mathrm{CH}_{2} \mathrm{Cl}_{2}(3 \mathrm{x})$. The collected organic extracts were dried $\left(\mathrm{MgSO}_{4}\right)$, and evaporated in vacuo. The residue was purified by flash chromatography (silica, 20\% EtOAc/hexane) to afford pure $\mathbf{1 3}$ $(12.2 \mathrm{~g}, 53 \%)$ as a slightly yellow oil: ${ }^{1} \mathrm{H}$ NMR $\left(\mathrm{CDCl}_{3}, 400 \mathrm{MHz}\right) \delta 5.82(\mathrm{~m}, 1 \mathrm{H}), 5.22(\mathrm{dd}, 1 \mathrm{H}$, $J=17.2,2.6 \mathrm{~Hz}), 5.18(\mathrm{dd}, 1 \mathrm{H}, J=10.4,2.4 \mathrm{~Hz}), 5.06(\mathrm{~s}, 1 \mathrm{H}), 4.79$ (d, 1H, $J=6.0 \mathrm{~Hz}), 4.57$ (d, $1 \mathrm{H}, 5.9), 4.36$ (s, 1H), 4.17 (dd, $1 \mathrm{H}, J=5.4,1.3 \mathrm{~Hz}), 4.02(\mathrm{dd}, 1 \mathrm{H}, J=6.4,1.2 \mathrm{~Hz}), 3.61$ (m, 2H), $3.17(\mathrm{dd}, 1 \mathrm{H}, J=10.1,3.2 \mathrm{~Hz}), 1.43(\mathrm{~s}, 3 \mathrm{H}), 1.26(\mathrm{~s}, 3 \mathrm{H}) ;{ }^{13} \mathrm{C} \mathrm{NMR}\left(\mathrm{CDCl}_{3}, 100 \mathrm{MHz}\right) \delta$ 133.0, 118.2, 112.2, 107.9, 88.3, 85.9, 81.4, 68.8, 63.9, 26.3, 24.6; IR (KBr) $v_{\max } 3462,3082$, $2941 \mathrm{~cm}^{-1}$; HRMS (ESI), $\mathrm{m} / z$ calcd for $\mathrm{C}_{11} \mathrm{H}_{18} \mathrm{O}_{5} \mathrm{Na}$ : 253.1052; found: 253.1031 . 


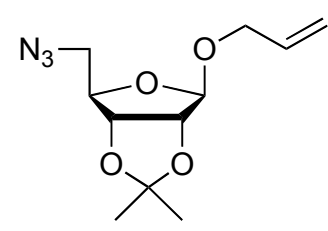

\section{4-Allyloxy-6-azidomethyl-2,2-dimethyltetrahydrofuro[3,4-d][1,3]dioxole}

(14). Zinc azide bis-pyridine $(32.4 \mathrm{~g}, 0.105 \mathrm{~mol})$ was slowly added to a solution of $\mathbf{1 3}$ (24.2 g, $0.105 \mathrm{~mol}), \mathrm{Ph}_{3} \mathrm{P}(53.2 \mathrm{~g}, 0.211 \mathrm{~mol})$, and diisopropyl azodicarboxylate $(41.2 \mathrm{~mL}, 0.211 \mathrm{~mol})$ in toluene $(450 \mathrm{~mL})$ at $0{ }^{\circ} \mathrm{C}$. The reaction mixture was stirred overnight $16 \mathrm{~h}$ at $25{ }^{\circ} \mathrm{C}$ and was evaporated in vасио. The residue was taken up in ether and triturated. The salts were filtered and the solvent was evaporated under reduced pressure. The crude product was purified by flash chromatography (silica, 10\% EtOAc/hexane) to afford pure 14 (25.2 g, 94\%) as a colorless oil: ${ }^{1} \mathrm{H}$ NMR $\left(\mathrm{CDCl}_{3}, 500 \mathrm{MHz}\right) \delta 5.93(\mathrm{~m}, 1 \mathrm{H}), 5.26(\mathrm{dd}, 1 \mathrm{H}, J=17.1 \mathrm{~Hz}, \mathrm{~J}=1.2 \mathrm{~Hz}), 5.19(\mathrm{dd}$, $1 \mathrm{H}, J=10.4 \mathrm{~Hz}, \mathrm{~J}=1.2 \mathrm{~Hz}), 5.12(\mathrm{~s}, 1 \mathrm{H}, \mathrm{C} 1-\mathrm{H}), 4.64(\mathrm{~d}, 1 \mathrm{H}, J=6.0 \mathrm{~Hz}), 4.59(\mathrm{~d}, 1 \mathrm{H}, J=6.3$ $\mathrm{Hz}), 4.28(\mathrm{t}, 1 \mathrm{H}, J=7.3 \mathrm{~Hz}), 4.21(\mathrm{ddm}, 1 \mathrm{H}, \mathrm{J}=12.9 \mathrm{~Hz}, \mathrm{~J}=5.2 \mathrm{~Hz}), 4.04(\mathrm{~m}, 1 \mathrm{H}), 3.45(\mathrm{dd}$, $1 \mathrm{H}, J=12.8,6.1 \mathrm{~Hz}), 3.26(\mathrm{dd}, 1 \mathrm{H}, J=12.8, \mathrm{~J}=7.9 \mathrm{~Hz}), 1.47(\mathrm{~s}, 3 \mathrm{H}), 1.30(\mathrm{~s}, 3 \mathrm{H}) ;{ }^{13} \mathrm{C} \mathrm{NMR}$ $\left(\mathrm{CDCl}_{3}, 125 \mathrm{MHz}\right) \delta 133.5,117.7,112.7,107.66,85.5,85.2,82.1,68.4,53.7,26.4,24.9 ; \mathrm{IR}$ (KBr) $v_{\max } 3082,2940,2103 \mathrm{~cm}^{-1}$; HRMS (ESI), $m / z$ calcd for $\mathrm{C}_{11} \mathrm{H}_{17} \mathrm{~N}_{3} \mathrm{O}_{4} \mathrm{Na}$ : 278.1117; found: 278.1117.

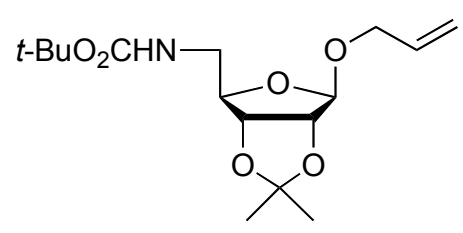

(6-Allyloxy-2,2-dimethyltetrahydrofuro[3,4-d][1,3]dioxol-4ylmethyl) Carbamic Acid, tert-Butyl Ester (15). A slurry of $\mathrm{Ph}_{3} \mathrm{P}(22.8 \mathrm{~g}, 87.0 \mathrm{mmol})$ was added to a solution of $\mathbf{1 4}(20.2 \mathrm{~g}, 79.13 \mathrm{mmol})$ in toluene $(325 \mathrm{~mL})$ at $25{ }^{\circ} \mathrm{C}$. The reaction mixture was stirred for $1 \mathrm{~h}$ at $25{ }^{\circ} \mathrm{C}$ and water $(68 \mathrm{~mL})$ was added. The reaction mixture was stirred for $12 \mathrm{~h}$ at $25{ }^{\circ} \mathrm{C}$ and was evaporated in vacuo. The residue was dissolved in $\mathrm{CH}_{2} \mathrm{Cl}_{2}(325$ $\mathrm{mL})$. Triethylamine $(80.4 \mathrm{~mL}, 0.58 \mathrm{~mol})$ was added followed by the addition of di-tert-butyl dicarbonate $(19.0 \mathrm{~g}, 87.1 \mathrm{mmol})$ at $0{ }^{\circ} \mathrm{C}$. The reaction mixture was stirred for $4 \mathrm{~h}$ at $25{ }^{\circ} \mathrm{C}$ and saturated aqueous $\mathrm{NaHCO}_{3}$ was added. The aqueous layer was extracted with $\mathrm{CH}_{2} \mathrm{Cl}_{2}(3 \times)$ and the combined organic extracts were dried $\left(\mathrm{MgSO}_{4}\right)$, and evaporated in vacuo. The crude product was purified by flash chromatography (20\% EtOAc/hexane) to afford $15(30.4 \mathrm{~g}, 100 \%)$ as a colorless oil that solidified on standing: ${ }^{1} \mathrm{H} \mathrm{NMR}\left(\mathrm{CDCl}_{3}, 500 \mathrm{MHz}\right) \delta 5.85(\mathrm{~m}, 1 \mathrm{H}), 5.27$ (app d, 
$1 \mathrm{H}, J=17.1 \mathrm{~Hz}), 5.16(\mathrm{app} \mathrm{d}, 1 \mathrm{H}, J=10.4 \mathrm{~Hz}), 5.07(\mathrm{br} \mathrm{s}, 2 \mathrm{H}), 4.61(\mathrm{~s}, 2 \mathrm{H}), 4.26(\mathrm{t}, 1 \mathrm{H}, J=5.5$ $\mathrm{Hz}), 4.15(\mathrm{~m}, 1 \mathrm{H}), 3.96(\mathrm{~m}, 1 \mathrm{H}), 3.27(\mathrm{br} \mathrm{s}, 2 \mathrm{H}), 1.44(\mathrm{~s}, 3 \mathrm{H}), 1.41(\mathrm{~s}, 9 \mathrm{H}), 1.28(\mathrm{~s}, 3 \mathrm{H}) ;{ }^{13} \mathrm{C}$ NMR $\left(\mathrm{CDCl}_{3}, 125 \mathrm{MHz}\right) \delta$ 156.8, 133.4, 117.4, 112.3, 107.8, 86.2, 85.6, 82.0, 79.5, 68.4, 43.6, 28.3, 26.4, 24.8; IR (KBr) $v_{\max } 3342,3058,2938,1694 \mathrm{~cm}^{-1}$; HRMS (ESI), $m / z$ calcd for $\mathrm{C}_{16} \mathrm{H}_{27} \mathrm{NO}_{6} \mathrm{Na}$ : 352.1736; found: 352.1749 .

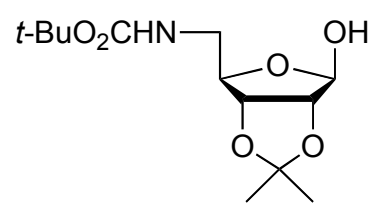

(6-Hyd roxy-2,2-dimethyltetrahyd rofuro [3,4-d][1,3]dioxol-4ylmethyl)carbamic Acid tert-Butyl Ester (16). A solution of $\mathrm{Et}_{3} \mathrm{Al}$ (1.9 $\mathrm{M}$ in toluene, $49.8 \mathrm{~mL}$ ) was slowly added to a solution of $\mathbf{1 5}(13.5 \mathrm{~g}, 41.41 \mathrm{mmol})$ and $\mathrm{NiCl}_{2}(\mathrm{dppp})(2.33 \mathrm{~g}, 4.14 \mathrm{mmol})$ in toluene $(490 \mathrm{~mL})$ at $0{ }^{\circ} \mathrm{C}$. The reaction mixture was stirred for $5 \mathrm{~min}$ at $0{ }^{\circ} \mathrm{C}$ and $4 \mathrm{~h}$ at $25^{\circ} \mathrm{C}$ and water $(50 \mathrm{~mL})$ was added. The reaction mixture was stirred for $1 \mathrm{~h}$ at $25^{\circ} \mathrm{C}$, filtered, and evaporated in vacuo. The residue was purified by flash chromatography ( $35 \%$ EtOAc/hexane) to afford $16(10.5 \mathrm{~g}, 86 \%)$ as a colorless oil: ${ }^{1} \mathrm{H}$ NMR $\left(\mathrm{CDCl}_{3}, 500 \mathrm{MHz}\right) \delta 5.43(\mathrm{~s}, 1 \mathrm{H}), 5.28(\mathrm{br}$, 1H), 4.60 (m, 2H), 4.40 (s, 1H), 4.19 (s, 1H), 3.38 (br m, 1H), 3.20 (br m, 1H), 1.44 (s, 3H), 1.42 (s, 9H), 1.29 (s, 3H); ${ }^{13} \mathrm{C} \mathrm{NMR}\left(\mathrm{CDCl}_{3}, 125 \mathrm{MHz}\right) \delta$ 156.9, 112.5, 103.1, 86.6, 86.4, 82.2, 80.0, 44.3, 28.5, 26.6, 25.0; IR (KBr) $v_{\max } 3342,3058,2938,1694 \mathrm{~cm}^{-1}$; HRMS (ESI), $m / z$ calcd for $\mathrm{C}_{13} \mathrm{H}_{23} \mathrm{NO}_{6} \mathrm{Na}: 312.1423$; found: 312.1432 .

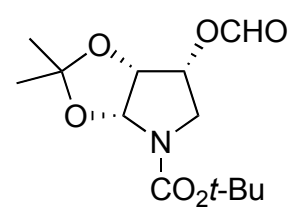

6-Formyloxy-2,2-dimethyltetrahydro-[1,3] dioxolo [4,5-b]pyrrole-4carboxylic Acid tert-Butyl Ester (17). Freshly prepared PhIO (14.9 g, $67.8 \mathrm{mmol})$ was slowly added to a solution of $\mathbf{1 6}(7.84 \mathrm{~g}, 27.1 \mathrm{mmol})$ and $\mathrm{I}_{2}(6.89 \mathrm{~g}, 27.1 \mathrm{mmol})$ in $\mathrm{CH}_{2} \mathrm{Cl}_{2}(1600 \mathrm{~mL})$ at $25{ }^{\circ} \mathrm{C}$. The reaction mixture was stirred for $24 \mathrm{~h}$ at $25{ }^{\circ} \mathrm{C}$ and a saturated aqueous $\mathrm{Na}_{2} \mathrm{~S}_{2} \mathrm{O}_{3}$ solution $(300 \mathrm{~mL})$ was added. The organic layer was washed with saturated aqueous $\mathrm{NaCl}$, dried $\left(\mathrm{MgSO}_{4}\right)$, and evaporated in vacuo. The residue was purified by flash chromatography (20\% EtOAc/hexane) to afford pure $17(7.79 \mathrm{~g}, 72 \%)$ as a colorless oil: ${ }^{1} \mathrm{H}$ NMR $\left(\mathrm{CDCl}_{3}, 500 \mathrm{MHz}\right.$, $\left.60{ }^{\circ} \mathrm{C}\right) \delta 8.04(\mathrm{~s}, 1 \mathrm{H}), 5.85(\mathrm{~s} \mathrm{br}, 1 \mathrm{H}), 4.95(\mathrm{~m}, 1 \mathrm{H}), 4.76(\mathrm{t}, 1 \mathrm{H}, J=9.2 \mathrm{~Hz}), 3.97$ (br m, 1H), 
$3.38(\mathrm{t}, 1 \mathrm{H}, J=10.4 \mathrm{~Hz}), 1.49(\mathrm{~s}, 3 \mathrm{H}), 1.44(\mathrm{~s}, 9 \mathrm{H}), 1.34(\mathrm{~s}, 3 \mathrm{H}) ;{ }^{13} \mathrm{C} \mathrm{NMR}\left(\mathrm{CDCl}_{3}, 125 \mathrm{MHz}\right) \delta$ 159.7, 153.5, 113.0, 81.0, 69.8, 60.2, 46.0, 28.4, 26.8, 26.3; IR (KBr) $v_{\max } 2982,2937,2891$, 1731, $1708 \mathrm{~cm}^{-1}$; HRMS (ESI), $\mathrm{m} / z$ calcd for $\mathrm{C}_{13} \mathrm{H}_{21} \mathrm{NO}_{6} \mathrm{Na}(\mathrm{M}+\mathrm{Na})$ : 310.1267 ; found: 310.1264 .

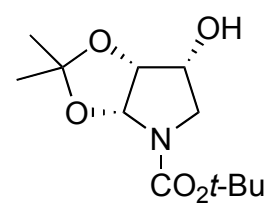

6-Hydroxy-2,2-dimethyltetrahydro-[1,3] dioxolo[4,5-b]pyrrole-4-carboxylic Acid tert-Butyl Ester (18). A solution of $17(3.50 \mathrm{~g}, 12.2 \mathrm{mmol})$ in $\mathrm{MeOH}(55 \mathrm{~mL})$ and $\mathrm{H}_{2} \mathrm{O}(5$ $\mathrm{mL})$ at room temperature was treated with $\mathrm{K}_{2} \mathrm{CO}_{3}(5.05 \mathrm{~g}, 36.6 \mathrm{mmol})$ for $4 \mathrm{~h}$. The solvent was removed under reduced pressure and the residue was diluted with $\mathrm{CH}_{2} \mathrm{Cl}_{2}(50 \mathrm{~mL})$. The organic phase was washed with water and the aqueous layer was extracted with $\mathrm{CH}_{2} \mathrm{Cl}_{2}(3 \times)$. The combined organic extracts were dried $\left(\mathrm{MgSO}_{4}\right)$ and concentrated in vacuo. The residue was purified by flash chromatography (50\% EtOAc/hexane) to afford $18(3.10 \mathrm{~g}, 97 \%)$ as a colorless solid: ${ }^{1} \mathrm{H}$ NMR $\left(\mathrm{CDCl}_{3}, 500 \mathrm{MHz}, 60{ }^{\circ} \mathrm{C}\right) \delta 5.85(\mathrm{~s} \mathrm{br}, 1 \mathrm{H}), 4.54(\mathrm{t}, 1 \mathrm{H}, J=4.9 \mathrm{~Hz}), 4.05$ (s br, $1 \mathrm{H}), 3.85-3.89(\mathrm{~m}, 1 \mathrm{H}), 3.10(\mathrm{dd}, 1 \mathrm{H}, J=9.2,10.6 \mathrm{~Hz}), 2.41$ (s br, $1 \mathrm{H}), 1.50(\mathrm{~s}, 3 \mathrm{H}), 1.46$ (s, 9H), 1.37 (s, 3H); ${ }^{13} \mathrm{C} \mathrm{NMR}\left(\mathrm{CDCl}_{3}, 125 \mathrm{MHz}\right) \delta$ 154.0, 112.8, 89.0, 81.0, 78.8, 69.9, 49.7, 28.6, 27.0, 26.6; IR (KBr) $v_{\max } 3442,2980,2935,1704 \mathrm{~cm}^{-1}$; HRMS (ESI), $\mathrm{m} / z$ calcd for $\mathrm{C}_{12} \mathrm{H}_{21} \mathrm{NO}_{5} \mathrm{Na}$ : 282.1317; found: 282.1324 .

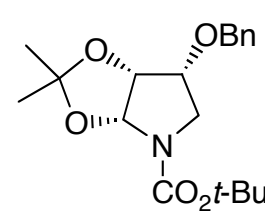

\section{6-Benzyloxy-2,2-dimethyltetrahydro-[1,3]dioxolo[4,5-b]pyrrole-4-carboxylic}

Acid tert-Butyl Ester (19). A slurry of $\mathrm{NaH}(19.2 \mathrm{mg}, 0.80 \mathrm{mmol})$ was added in one portion to a solution of $22(102 \mathrm{mg}, 0.40 \mathrm{mmol})$ and $n$-Bu 4 NI $(15.0 \mathrm{mg}, 0.04 \mathrm{mmol})$ in THF $(4 \mathrm{~mL})$ and DMF $(0.4 \mathrm{~mL})$ at $0{ }^{\circ} \mathrm{C}$. The reaction mixture was stirred for $30 \mathrm{~min}$ at $0{ }^{\circ} \mathrm{C}$ and benzyl bromide $(0.070 \mathrm{~mL}, 0.60 \mathrm{mmol})$ was added. The mixture was stirred for $1 \mathrm{~h}$ at $0{ }^{\circ} \mathrm{C}$ and saturated aqueous $\mathrm{NaHCO}_{3}(4 \mathrm{~mL})$ was added. The aqueous layer was extracted with EtOAc $(3 \times)$ and the combined organic extracts were washed with saturated aqueous $\mathrm{NaCl}(4 \mathrm{~mL})$, dried $\left(\mathrm{Na}_{2} \mathrm{SO}_{4}\right)$, filtered, and the filtrated was evaporated in vacuo. The residue was purified by flash 
chromatography (silica, 15\% EtOAc/hexane) to afford pure $\mathbf{2 4}(84.3 \mathrm{mg}, 89 \%)$ as a white solid: ${ }^{1} \mathrm{H}$ NMR $\left(\mathrm{CDCl}_{3}, 500 \mathrm{MHz}\right) \delta$ 7.39-7.25 (br, 5H), 5.80-5.75, 5.67-5.61(2 parts, br, 1H), 4.714.54 (br m, 3H), 3.85-3.71 (br m, 1H), 3.70-3.63 (br t, 1H), 3.23 (br t, 1H), 1.51 (br d, 3H), 1.43 (s, 9H), 1.34 (br s, 3H); $\left.{ }^{13} \mathrm{C} \mathrm{NMR} \mathrm{(CDCl3,} 125 \mathrm{MHz}\right) \delta 153.91$ (153.68, rotamer), 137.52 (137.47), 128.5, 128.07 (128.00), 112.71 (112.58), 88.2 (88.05), 80.6, 78.3, 75.38 (74.85), 72.1, 46.75 (45.94), 28. 3, 27.1, 26.37 (26.10); HRMS (ESI), $m / z$ calcd for $\mathrm{C}_{19} \mathrm{H}_{27} \mathrm{NO}_{5} \mathrm{Na}: 372.1787$; found: 372.1798 .

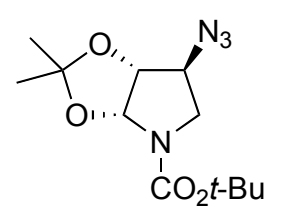

6-Azido-2,2-dimethyltetrahydro-[1,3]dioxolo[4,5-b]pyrrole-4-carboxylic Acid tert-Butyl Ester (22). Diphenylphosphoryl azide $(0.73 \mathrm{~mL}, 3.37 \mathrm{mmol})$ was slowly added to a solution of alcohol 18 (437 mg, $1.69 \mathrm{mmol}), \mathrm{Ph}_{3} \mathrm{P}(884 \mathrm{mg}, 3.37 \mathrm{mmol})$ and diisopropyl azodicarboxylate $(0.66 \mathrm{~mL}, 3.37 \mathrm{mmol})$ in THF $(6 \mathrm{~mL})$ at $0{ }^{\circ} \mathrm{C}$. The reaction mixture was allowed to warm to room temperature and was stirred overnight. The solvent was removed and the residue was dissolved in ether. The resulting white precipitate was filtered and the filtrate was concentrated under reduced pressure. The residue was purified by flash chromatography (5\% EtOAc/toluene) to afford azide 22 (479 mg, 97\%) as a colorless oil: ${ }^{1} \mathrm{H}$ NMR $\left(\mathrm{CDCl}_{3}, 500\right.$ $\left.\mathrm{MHz}, 60^{\circ} \mathrm{C}\right) \delta 5.97(\mathrm{~s} \mathrm{br}, 1 \mathrm{H}), 4.53(\mathrm{~d}, 1 \mathrm{H}, J=4.6 \mathrm{~Hz}), 3.95(\mathrm{~d}, 1 \mathrm{H}, J=4.1 \mathrm{~Hz}), 3.79(\mathrm{~s} \mathrm{br}, 1 \mathrm{H})$, $3.64(\mathrm{dd}, 1 \mathrm{H}, J=4.2,12.3 \mathrm{~Hz}), 1.53(\mathrm{~s}, 9 \mathrm{H}), 1.47$ (s, 3H), 1.37 (s, 3H); ${ }^{13} \mathrm{C} \mathrm{NMR}_{\left(\mathrm{CDCl}_{3}, 125\right.}$ $\left.\mathrm{MHz}, 60^{\circ} \mathrm{C}\right) \delta 153.7,112.1,89.0,83.1,81.1,63.2,48.6,28.5,27.1,26.2 ; \mathrm{IR}(\mathrm{KBr}) v_{\max } 2978$, 2109, $1710 \mathrm{~cm}^{-1}$; HRMS (ESI), $m / z$ calcd for $\mathrm{C}_{12} \mathrm{H}_{20} \mathrm{~N}_{4} \mathrm{O}_{4} \mathrm{Na}$ : 307.1377; found: 307.1390 .

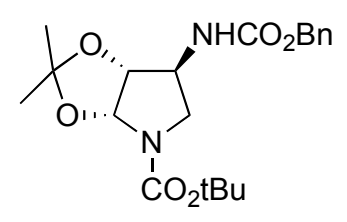

6-Carbobenzyloxyamino-2,2-dimethyltetrahydro-[1,3]dioxolo $[4,5-b]$ pyrrole-4-carboxylic Acid tert-Butyl Ester (23). Azide $22(1 \mathrm{~g}, 3.52 \mathrm{mmol})$ in $\mathrm{CH}_{3} \mathrm{CN}(15 \mathrm{~mL})$ was added to a solution of $\mathrm{SnCl}_{2}(1.07 \mathrm{~g}, 5.63 \mathrm{mmol})$, thiophenol $(1.73 \mathrm{~mL}, 16.9 \mathrm{mmol})$ and $\mathrm{Et}_{3} \mathrm{~N}(2.35 \mathrm{~mL}, 16.9 \mathrm{mmol})$ in $\mathrm{CH}_{3} \mathrm{CN}(30 \mathrm{~mL})$ at room temperature. The resulting mixture was stirred for $1 \mathrm{~h}$ and then, diluted with $\mathrm{CH}_{2} \mathrm{Cl}_{2}$ and washed twice with $2 \mathrm{~N} \mathrm{NaOH}$ solution. The aqueous phase was extracted with $\mathrm{CH}_{2} \mathrm{Cl}_{2}(3 \times)$. The collected organic extracts were dried 
$\left(\mathrm{MgSO}_{4}\right)$, filtered, and concentrated under reduced pressure to give the crude amine. The residue was dissolved in $\mathrm{CH}_{2} \mathrm{Cl}_{2}(70 \mathrm{~mL})$ and treated by $\mathrm{Et}_{3} \mathrm{~N}(2.45 \mathrm{~mL}, 17.6 \mathrm{mmol})$ and benzyl chloroformate $(2.00 \mathrm{~mL}, 14.08 \mathrm{mmol})$ at $0{ }^{\circ} \mathrm{C}$. After being stirred during $2 \mathrm{~h}$, the solution was washed with saturated $\mathrm{NaHCO}_{3}$ aqueous solution. The aqueous phase was extracted three times with $\mathrm{CH}_{2} \mathrm{Cl}_{2}$. The collected organic extracts were dried $\left(\mathrm{MgSO}_{4}\right)$, filtered and concentrated in vacuo. Purification by flash chromatography (silica, 25\% EtOAc/hexane) afforded 23 (1.20 g, $79 \%$ ) as a colorless oil: ${ }^{1} \mathrm{H} \mathrm{NMR}\left(\mathrm{CDCl}_{3}, 500 \mathrm{MHz}, 50{ }^{\circ} \mathrm{C}\right) \delta$ 7.30-7.37 (m, 5H), 5.85 (s br, $\left.1 \mathrm{H}\right)$, $5.12(\mathrm{~s}, 2 \mathrm{H}), 4.75$ (s br, 1H), 4.52 (s br, 1H), 4.11-4.17 (m, 1H), 3.66 (dd, 1H, J = 4.7 , $11.9 \mathrm{~Hz})$, $3.53(\mathrm{~d}, 1 \mathrm{H}, \mathrm{J}=11.9 \mathrm{~Hz}), 1.48(\mathrm{~s}, 9 \mathrm{H}), 1.45$ (s, 3H), $1.32(\mathrm{~s}, 3 \mathrm{H}) ;{ }^{13} \mathrm{C} \mathrm{NMR}\left(\mathrm{CDCl}_{3}, 125 \mathrm{MHz}\right.$, $\left.50{ }^{\circ} \mathrm{C}\right) \delta 155.7,154.1,136.4,128.6,128.3,128.3,111.8,88.5,85.5,80.9,67.2,54.7,49.4,28.5$, 27.1, 26.1; IR (KBr) $v_{\max }$ 3315, 2979, 2930, $1697 \mathrm{~cm}^{-1}$; HRMS (ESI), $\mathrm{m} / z$ calcd for $\mathrm{C}_{20} \mathrm{H}_{28} \mathrm{~N}_{2} \mathrm{O}_{6} \mathrm{Na}$ : 415.1840; found: 415.1842 .<smiles>COC(=O)/C=C/CN(C(=O)OC)C(=O)OC(C)(C)C</smiles>

\section{4 - [ t e r t-Butoxycarbonyl-(4-methoxybenzyl)amino]but-2-enoic} acid methyl ester (25). $p$-Methoxybenzylamine (1.43 mL, $11.0 \mathrm{mmol})$ was slowly added to a solution of methyl 4-bromocrotonate $(1.40 \mathrm{~mL}, 10.0 \mathrm{mmol})$ and $\operatorname{EtN}(i-\operatorname{Pr})_{2}(6.64 \mathrm{~mL}, 33.0$ $\mathrm{mmol})$ in THF $(50 \mathrm{~mL})$ at $25^{\circ} \mathrm{C}$. The reaction mixture was stirred for $12 \mathrm{~h}$ at $25^{\circ} \mathrm{C}$ and saturated aqueous $\mathrm{NaHCO}_{3}(50 \mathrm{~mL})$ was added. The aqueous layer was extracted with EtOAc $(3 \times)$ and the combined organic extracts were dried $\left(\mathrm{Na}_{2} \mathrm{SO}_{4}\right)$, filtered, and the filtrate was evaporated in vacuo. The residue was dissolved in $\mathrm{CH}_{2} \mathrm{Cl}_{2}(50 \mathrm{~mL})$ at $25{ }^{\circ} \mathrm{C}$ and $\mathrm{Et}_{3} \mathrm{~N}(3.34 \mathrm{~mL}, 24.0 \mathrm{mmol})$ and $(t-\mathrm{BuOCO})_{2} \mathrm{O}(2.76 \mathrm{~mL}, 12.0 \mathrm{mmol})$ were added. The reaction mixture was stirred for $3 \mathrm{~h}$ at $25^{\circ} \mathrm{C}$ and saturated aqueous $\mathrm{NaHCO}_{3}(50 \mathrm{~mL})$ was added. The aqueous layer was extracted with EtOAc $(3 \times)$ and the combined organic extracts were dried $\left(\mathrm{Na}_{2} \mathrm{SO}_{4}\right)$, filtered, and the filtrate was evaporated in vacuo. The residue was purified by flash chromatography (silica, 10\% EtOAc/hexane) to afford pure $25(2.35 \mathrm{~g}, 71 \%)$ as a colorless oil: ${ }^{1} \mathrm{H} \mathrm{NMR}\left(\mathrm{CDCl}_{3}, 500 \mathrm{MHz}\right.$, $\left.60^{\circ} \mathrm{C}\right) \delta 7.12(\mathrm{~d}, 2 \mathrm{H}, J=8.5 \mathrm{~Hz}), 6.84(\mathrm{~d}, 2 \mathrm{H}, J=8.5 \mathrm{~Hz}), 6.79(\mathrm{~m}, 1 \mathrm{H}), 5.82(\mathrm{~d}, 1 \mathrm{H}, J=15.9$ Hz), 4.35 (br, 2H), 3.88 (br, 2H), 3.77 (s, 3H), 3.72 (s, 3H), 1.47 (s, 9H); HRMS (ESI), m/z calcd for $\mathrm{C}_{18} \mathrm{H}_{25} \mathrm{NO}_{5} \mathrm{Na}$ : 358.1631; found: 358.1617. 


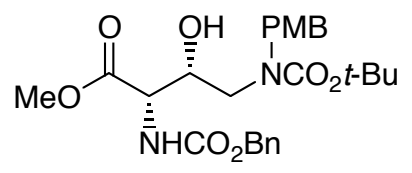

\section{2-Benzyloxycarbonylamino-4-tert-butoxycarbonyl-(4-methoxy}

benzyl) amino-3-hydroxy butyric acid methyl ester (26). A slurry of benzyl carbamate (234 $\mathrm{mg}, 1.55 \mathrm{mmol}$ ) was added in one portion to a solution of $\mathrm{NaOH}(60.0 \mathrm{mg}, 1.50 \mathrm{mmol})$ in $\mathrm{H}_{2} \mathrm{O}$ $(3.8 \mathrm{~mL})$ and $n$ - $\mathrm{PrOH}(2.3 \mathrm{~mL})$ at $25^{\circ} \mathrm{C}$. After the solution was completely clear, $t$ - $\mathrm{BuOCl}(0.17$

$\mathrm{mL}, 1.50 \mathrm{mmol}$ ) was added to the reaction mixture and the solution was stirred in the dark for 5 min at $25{ }^{\circ} \mathrm{C}$. The reaction mixture was cooled to $0{ }^{\circ} \mathrm{C}$ in the dark and a solution of (DHQD) ${ }_{2} \mathrm{AQN}(21 \mathrm{mg}, 0.025 \mathrm{mmol})$ in $n-\mathrm{PrOH}(2.0 \mathrm{~mL})$ was added followed by the addition of $31(167 \mathrm{mg}, 0.50 \mathrm{mmol})$ and $\mathrm{K}_{2} \mathrm{OsO}_{4} \cdot 2 \mathrm{H}_{2} \mathrm{O}(7.4 \mathrm{mg}, 0.020 \mathrm{mmol})$. The reaction mixture was stirred for $6 \mathrm{~h}$ at $0{ }^{\circ} \mathrm{C}$ in the dark and saturated aqueous $\mathrm{Na}_{2} \mathrm{~S}_{2} \mathrm{O}_{3}(5 \mathrm{~mL})$ was added. The aqueous layer was extracted with EtOAc $(3 \times)$ and the combined organic extracts were dried $\left(\mathrm{Na}_{2} \mathrm{SO}_{4}\right)$, filtered, and the filtrate was evaporated in vacuo. The residue was purified by flash chromatography (silica, 5\% acetone $/ \mathrm{CH}_{2} \mathrm{Cl}_{2}$ ) to afford $\mathbf{2 6}(168.2 \mathrm{mg}, 67 \%)$ as a colorless oil, with slight contamination of benzyl carbamate that was used without further purification.<smiles>COC(=O)[C@H](NC(=O)OCc1ccccc1)[C@H](O)CNC(=O)OCc1ccccc1</smiles>

2-Benzyloxycarbonylamino-4-tert-butoxycarbonylamino-3-hydroxy butyric acid methyl ester. A solution of $\left(\mathrm{NH}_{4}\right)_{3} \mathrm{Ce}\left(\mathrm{NO}_{3}\right)_{6}(605 \mathrm{mg}, 1.1 \mathrm{mmol})$ in $\mathrm{H}_{2} \mathrm{O}(2 \mathrm{~mL})$ was added to a solution of crude $26(168.2 \mathrm{mg}, 0.34 \mathrm{mmol})$ in $\mathrm{CH}_{3} \mathrm{CN}(6 \mathrm{~mL})$ at $25^{\circ} \mathrm{C}$. The reaction mixture was stirred for $5 \mathrm{~min}$ at $25^{\circ} \mathrm{C}$ and EtOAc $(5 \mathrm{~mL})$ was added. The aqueous layer was extracted with EtOAc $(3 \times)$ and the combined organic extracts were dried $\left(\mathrm{Na}_{2} \mathrm{SO}_{4}\right)$, filtered, and the filtrate was evaporated in vacuo. The residue was purified by flash chromatography (silica, 20\% EtOAc/hexane) to afford the pure carbamate (112.0 $\mathrm{mg}, 56 \%$ for 2 steps) as a white solid: ${ }^{1} \mathrm{H}$ NMR $\left(\mathrm{CDCl}_{3}, 500 \mathrm{MHz}\right) \delta 7.32(\mathrm{~m}, 5 \mathrm{H}), 5.80$ (br, $\left.1 \mathrm{H}\right), 5.28$ (br, $\left.1 \mathrm{H}\right), 5.10$ (br s, $\left.2 \mathrm{H}\right)$, 4.44 (br, 1H), 4.20 (br, 1H), 3.76 (br, 1H), 3.73 (s, 3H), 3.35 (br, 1H), 3.00 (br, 1H), 1.40 (s, 9H); ${ }^{13} \mathrm{C} \mathrm{NMR}\left(\mathrm{CDCl}_{3}, 125 \mathrm{MHz}\right) \delta 170.8,159.3,156.1,136.2,128.4,128.1,127.9,80.0,71.6,67.2$, 56.5, 44.0, 28.3; HRMS (ESI), $m / z$ calcd for $\mathrm{C}_{18} \mathrm{H}_{26} \mathrm{~N}_{2} \mathrm{O}_{7} \mathrm{Na}$ : 405.1638; found: 405.1609. 
<smiles>CC(C)(C)OC(=O)N1C[C@H](O)C(NC=O)C1O</smiles>

\section{3-Benzyloxycarbonylamino-2,4-dihydroxypyrrolidine-1-carboxylic Acid}

tert-Butyl Ester (27). A solution of $i-\mathrm{Bu}_{2} \mathrm{AlH}(1.0 \mathrm{M}$ in THF, $1.21 \mathrm{~mL})$ was slowly added to a solution of the above carbamate $(84.8 \mathrm{mg}, 0.22 \mathrm{mmol})$ in $\mathrm{THF}(2 \mathrm{~mL})$ at $-78{ }^{\circ} \mathrm{C}$. The reaction mixture was stirred for $14 \mathrm{~h}$ at $-78^{\circ} \mathrm{C}$ and aqueous $\mathrm{K}_{2} \mathrm{HPO}_{4} / \mathrm{KH}_{2} \mathrm{PO}_{4}$ buffer $(1.0 \mathrm{M}, \mathrm{pH} 7,5 \mathrm{~mL})$ was added. The aqueous layer was extracted with EtOAc $(3 \times)$ and the combined organic extracts were dried $\left(\mathrm{Na}_{2} \mathrm{SO}_{4}\right)$, filtered, and the filtrate was evaporated in vacuo. The residue was purified by flash chromatography (silica, 25\% EtOAc/hexane) to afford pure $27(61.5 \mathrm{mg}, 67 \%)$ as an unstable pale yellow oil: ${ }^{1} \mathrm{H}$ NMR $\left(\mathrm{CDCl}_{3}, 500 \mathrm{MHz}, 60{ }^{\circ} \mathrm{C}\right) \delta 7.33(\mathrm{~m}, 5 \mathrm{H}), 5.60-5.20(\mathrm{br}, 2 \mathrm{H})$, 5.12 (br, 2H), 4.40-4.15 (br, 1H), 3.97 (br, 1H), 3.83-3.43 (br, 2H), 3.15 (m, 1H), 1.47 (s, 9H); ${ }^{13} \mathrm{C} \mathrm{NMR}\left(\mathrm{CDCl}_{3}, 125 \mathrm{MHz}\right) \delta 160.8,154.8,135.9,128.6,128.3,128.2,81.1,79.1,74.8,67.4$, 59.5, 50.3, 28.3; HRMS (ESI), $m / z$ calcd for $\mathrm{C}_{17} \mathrm{H}_{24} \mathrm{~N}_{2} \mathrm{O}_{6} \mathrm{Na}$ : 375.1532; found: 375.1558 .<smiles>COc1ccc(C=O)c(OC)c1C</smiles>

2,4-Dimethoxy-3-methylbenzaldehyde (29). A solution of $\mathrm{SnCl}_{4}(1.0 \mathrm{M}$ in $\mathrm{CH}_{2} \mathrm{Cl}_{2}, 95 \mathrm{~mL}, 95 \mathrm{mmol}$ ) was added dropwise to a solution of 2,6-dimethoxytoluene 28 (11.11 g, $73.09 \mathrm{mmol})$ in $\mathrm{CH}_{2} \mathrm{Cl}_{2}(220 \mathrm{~mL})$ at $0{ }^{\circ} \mathrm{C}$. The reaction mixture was stirred for $1 \mathrm{~h}$ at 0 ${ }^{\circ} \mathrm{C}$ and $\mathrm{Cl}_{2} \mathrm{CHOCH}_{3}$ [CAUTION: HIGHLY TOXIC; LACHRYMATOR] (7.94 mL, $87.7 \mathrm{mmol}$ ) was slowly added. The reaction mixture was stirred for $1 \mathrm{~h}$ at $0{ }^{\circ} \mathrm{C}$ and was allowed to warm to $25^{\circ} \mathrm{C}$. The reaction mixture was poured onto crushed ice $(40 \mathrm{~mL})$ and was stirred for $1 \mathrm{~h}$ at 25 ${ }^{\circ} \mathrm{C}$. The aqueous layer was extracted with EtOAc $(3 \times)$ and the combined organic extracts were washed with saturated aqueous $\mathrm{NaHCO}_{3}$ and saturated aqueous $\mathrm{NaCl}$, dried $\left(\mathrm{MgSO}_{4}\right)$, filtered, and the filtrate was evaporated in vacuo. Recrystallization of the residue from hexane afforded 29 as colorless, needle-like crystals (12.36 g, 94\%): ${ }^{1} \mathrm{H}$ NMR $\left(\mathrm{CDCl}_{3}, 400 \mathrm{MHz}\right) \delta 10.20(\mathrm{~s}, 1 \mathrm{H})$, $7.71(\mathrm{~d}, 1 \mathrm{H}, J=8.8 \mathrm{~Hz}), 6.71(\mathrm{~d}, 1 \mathrm{H}, J=8.7 \mathrm{~Hz}), 3.88(\mathrm{~s}, 3 \mathrm{H}), 3.83(\mathrm{~s}, 3 \mathrm{H}), 2.14(\mathrm{~s}, 3 \mathrm{H}) ;{ }^{13} \mathrm{C}$ NMR $\left(\mathrm{CDCl}_{3}, 100 \mathrm{MHz}\right) \delta 189.2,164.1,162.7,128.0,122.9,120.2,106.6,63.2,56.0,8.6$; HRMS (ESI), $m / z$ calcd for $\mathrm{C}_{10} \mathrm{H}_{12} \mathrm{O}_{3} \mathrm{Na}$ : 203.0679; found: 203.0693 . 
<smiles>COc1ccc(O)c(OC)c1C</smiles>

2,4-Dimethoxy-3-methylphenol (30). $m$-Chloroperbenzoic acid (33.8 g, $0.137 \mathrm{~mol})$ was added in one portion to a solution of $29(12.4 \mathrm{~g}, 68.7 \mathrm{mmol})$ in $\mathrm{CH}_{2} \mathrm{Cl}_{2}(185 \mathrm{~mL})$ at $0{ }^{\circ} \mathrm{C}$, and the reaction mixture was stirred for $3 \mathrm{~h}$ at $0{ }^{\circ} \mathrm{C}$. The reaction mixture was washed with saturated aqueous $\mathrm{K}_{2} \mathrm{CO}_{3}(3 \times)$ and the solvent was evaporated in vacuo. The residue was dissolved in $\mathrm{MeOH}(120 \mathrm{~mL})$ at $0{ }^{\circ} \mathrm{C}$ and $\mathrm{KOH}(5.77 \mathrm{~g}, 0.103 \mathrm{mmol})$ was added. The reaction mixture was stirred for $1 \mathrm{~h}$ at $0{ }^{\circ} \mathrm{C}$ and the solvent evaporated in vacuo. The residue was dissolved in ether $(300 \mathrm{~mL})$ and acidified with aqueous $3 \mathrm{~N} \mathrm{HCl}$. The organic layer was washed with water $(2 \mathrm{x})$, saturated aqueous $\mathrm{NaCl}$, dried $\left(\mathrm{MgSO}_{4}\right)$, and evaporated in vacuo. Purification of the residue by flash chromatography (silica, 20\% EtOAc-hexane) afforded pure 30 (10.1 g, 87\%) as a yellow oil: ${ }^{1} \mathrm{H} \mathrm{NMR}\left(\mathrm{CDCl}_{3}, 400 \mathrm{MHz}\right) \delta 6.76(\mathrm{~d}, 1 \mathrm{H}, J=8.8 \mathrm{~Hz}), 6.54(\mathrm{~d}, 1 \mathrm{H}, J=$ $8.8 \mathrm{~Hz}), 5.48(\mathrm{~s}, 1 \mathrm{H}), 3.78(\mathrm{~s}, 6 \mathrm{H}), 2.19(\mathrm{~s}, 3 \mathrm{H}) ;{ }^{13} \mathrm{C} \mathrm{NMR}\left(\mathrm{CDCl}_{3}, 100 \mathrm{MHz}\right) \delta 152.0,146.1$, 143.0, 120.1, 111.8, 106.9, 60.9, 56.1, 9.4; IR (KBr) $v_{\max } 3425,2942 \mathrm{~cm}^{-1}$.

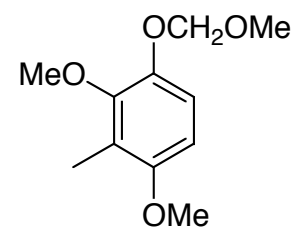

1,3-Dimethoxy-4-methoxymethoxy-2-methylbenzene (31). A slurry of $\mathrm{NaH}$ (3.26 g, $136 \mathrm{mmol})$ was added in one portion to a solution of $\mathbf{3 0}(11.4 \mathrm{~g}, 68.0 \mathrm{mmol})$ in THF $(340 \mathrm{~mL})$ and DMF $(34 \mathrm{~mL})$ at $0{ }^{\circ} \mathrm{C}$. The reaction mixture was stirred $1 \mathrm{~h}$ at $25^{\circ} \mathrm{C}$ and chloromethyl methyl ether [CAUTION: HIGHLY TOXIC; LACHRYMATOR] (5.68 mL, 74.8 mmol) was slowly added. The reaction mixture was stirred $1 \mathrm{~h}$ at $25^{\circ} \mathrm{C}$ and ether $(500 \mathrm{~mL})$ was added. The reaction mixture was washed with saturated aqueous $\mathrm{NaHCO}_{3}(100 \mathrm{~mL})$ and saturated aqueous $\mathrm{NaCl}(100 \mathrm{~mL})$. The organic layer was dried $\left(\mathrm{Na}_{2} \mathrm{SO}_{4}\right)$, filtered, and the filtrate was evaporated in vacuo. The residue was distilled under vacuum to afford $\mathbf{3 1}$ as a colorless oil (11.72 g, 89\%, $\left.64{ }^{\circ} \mathrm{C} / 0.2 \mathrm{~mm} \mathrm{Hg}\right):{ }^{1} \mathrm{H} \mathrm{NMR}\left(\mathrm{CDCl}_{3}, 500 \mathrm{MHz}\right) \delta 6.90(\mathrm{~d}, 1 \mathrm{H}, J=9.2 \mathrm{~Hz}), 6.51$ $(\mathrm{d}, 1 \mathrm{H}, J=9.2 \mathrm{~Hz}), 5.12(\mathrm{~s}, 2 \mathrm{H}), 3.79(\mathrm{~s}, 3 \mathrm{H}), 3.76(\mathrm{~s}, 3 \mathrm{H}), 3.50(\mathrm{~s}, 3 \mathrm{H}), 2.13(\mathrm{~s}, 3 \mathrm{H}) ;{ }^{13} \mathrm{C}$ NMR $\left(\mathrm{CDCl}_{3}, 125 \mathrm{MHz}\right) \delta 153.6,149.3,144.4,129.9,114.5,105.5,96.1,60.5,56.1,55.9,9.0$; HRMS (ESI), $m / z$ calcd for $\mathrm{C}_{11} \mathrm{H}_{16} \mathrm{O}_{4} \mathrm{Na}$ : 235.0947; found: 235.0933. 


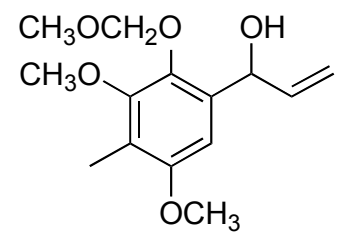

1-(3,5-Dimethoxy-2-methoxymethoxy-4-methylphenyl)prop-2-en-1-ol

(32). A solution of $n$-BuLi $(2.32 \mathrm{M}$ in hexane, $37.0 \mathrm{~mL}, 86.0 \mathrm{mmol})$ was slowly added to a solution of $31(11.4 \mathrm{~g}, 53.8 \mathrm{mmol})$ in THF $(200 \mathrm{~mL})$ at $0{ }^{\circ} \mathrm{C}$. The reaction mixture was stirred for $1 \mathrm{~h}$ at $0{ }^{\circ} \mathrm{C}$ and freshly distilled acrolein $(4.82 \mathrm{~mL}, 71.5 \mathrm{mmol})$ was added. The reaction mixture was allowed to warm to $25{ }^{\circ} \mathrm{C}$ and saturated aqueous $\mathrm{NaHCO}_{3}$ was added. The aqueous layer was extracted with $\mathrm{CH}_{2} \mathrm{Cl}_{2}(3 \times)$ and the combined organic extracts were dried $\left(\mathrm{MgSO}_{4}\right)$, filtered, and the filtrate was evaporated in vacuo. The residue was purified by flash chromatography (silica, 25\% EtOAc-hexane) to afford pure $32(12.4 \mathrm{~g}, 86 \%)$ as a colorless oil: ${ }^{1} \mathrm{H} \mathrm{NMR}\left(\mathrm{CDCl}_{3}\right.$, $400 \mathrm{MHz}) \delta 6.60(\mathrm{~s}, 1 \mathrm{H}), 6.07-6.12(\mathrm{~m}, 1 \mathrm{H}), 5.53-5.55(\mathrm{~m}, 1 \mathrm{H}), 5.43(\mathrm{dd}, 1 \mathrm{H}, J=17.2 \mathrm{~Hz}, \mathrm{~J}=$ $1.5 \mathrm{~Hz}), 5.24(\mathrm{dd}, 1 \mathrm{H}, J=10.5 \mathrm{~Hz}, \mathrm{~J}=1.5 \mathrm{~Hz}), 5.06(\mathrm{dd}, 1 \mathrm{H}, J=5.8,16.1 \mathrm{~Hz}), 3.78(\mathrm{~s}, 3 \mathrm{H})$, 3.76 (s, 3H), 3.56 (s, 3H), 3.26 (br s, $1 \mathrm{H}), 2.11$ (s, 3H); ${ }^{13} \mathrm{C}$ NMR $\left(\mathrm{CDCl}_{3}, 100 \mathrm{MHz}\right) \delta 154.9$, $151.4,142.1,139.2,134.2,120.8,114.8,104.3,99.8,69.2,60.3,57.6,55.8,9.0$; IR (KBr) $v_{\max }$ 3453, 3087, 2938, $1641 \mathrm{~cm}^{-1}$; HRMS (ESI), $\mathrm{m} / z$ calcd for $\mathrm{C}_{14} \mathrm{H}_{20} \mathrm{O}_{5} \mathrm{Na}$ : 291.1203; found: 291.1180.

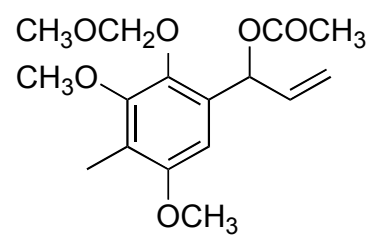

Acetic acid 1-(3,5-dimethoxy-2-methoxymethoxy-4-methyl

phenyl)allyl ester (33). Acetic anhydride $(8.70 \mathrm{~mL}, 92.3 \mathrm{mmol})$ was slowly added to a solution of 32 (12.37 g, $46.16 \mathrm{mmol}), \mathrm{Et}_{3} \mathrm{~N}(19.3 \mathrm{~mL}, 0.138 \mathrm{~mol})$ and 4-( $N, N$-dimethylamino)pyridine (catalytic) in $\mathrm{CH}_{2} \mathrm{Cl}_{2}(190 \mathrm{~mL})$ at $25^{\circ} \mathrm{C}$. The reaction mixture was stirred for $3 \mathrm{~h}$ at $25{ }^{\circ} \mathrm{C}$ and saturated aqueous $\mathrm{NaHCO}_{3}$ was added. The aqueous layer was extracted with $\mathrm{CH}_{2} \mathrm{Cl}_{2}(3 \times)$ and the combined organic extracts were dried $\left(\mathrm{MgSO}_{4}\right)$, filtered, and the filtrate was evaporated in vacuo. The residue was purified by flash chromatography (silica, 25\% EtOAc-hexane) to afford pure $33(12.7 \mathrm{~g}, 89 \%)$ as a colorless oil: ${ }^{1} \mathrm{H} \mathrm{NMR}\left(\mathrm{CDCl}_{3}, 400 \mathrm{MHz}\right) \delta 6.70(\mathrm{dt}, 1 \mathrm{H}, J=5.1,1.5$ Hz), 6.59 (s, 1H), 6.04 (ddd, 1H, $J=5.12,10.5,17.2 \mathrm{~Hz}), 5.20-5.29$ (m, 2H), 5.08 (s, 2H), 3.80 (s, 3H), 3.78 (s, 3H), 3.61 (s, 3H), $2.12(\mathrm{~s}, 3 \mathrm{H}), 2.10(\mathrm{~s}, 3 \mathrm{H}) ;{ }^{13} \mathrm{C} \mathrm{NMR}\left(\mathrm{CDCl}_{3}, 100 \mathrm{MHz}\right) \delta$ 169.8, 154.8, 151.7, 141.6, 136.3, 130.0, 121.4, 116.1, 104.4, 99.6, 70.8, 60.4, 57.8, 55.9, 21.3, 
9.1; IR (KBr) $v_{\max } 2937,1743,1643 \mathrm{~cm}^{-1}$; HRMS (ESI), $m / z$ calcd for $\mathrm{C}_{16} \mathrm{H}_{22} \mathrm{O}_{6} \mathrm{Na}$ : 333.1314; found: 333.1309 .

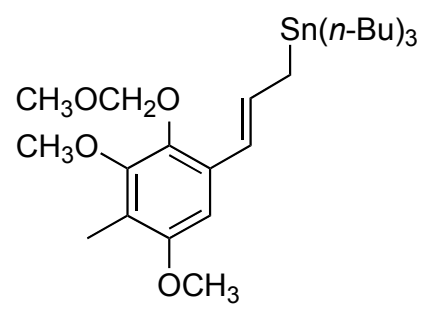

Tri-n-butyl-[3-(3,5-dimethoxy-2-(methoxy) methoxy-4-

methylphenyl)allyl]stannane (34). A solution of $\mathrm{SmI}_{2}(0.1 \mathrm{M}$ in THF, $95 \mathrm{~mL})$ was added over 2 $\mathrm{h}$ to a solution of $33(1.18 \mathrm{~g}, 3.81 \mathrm{mmol}), \mathrm{Pd}\left(\mathrm{PPh}_{3}\right)_{4}(220 \mathrm{mg}, 0.19 \mathrm{mmol})$, and $n-\mathrm{Bu} 3 \mathrm{SnCl}(1.54$ $\mathrm{mL}, 5.71 \mathrm{mmol})$ in $\mathrm{THF}(10 \mathrm{~mL})$ at $0{ }^{\circ} \mathrm{C}$. The reaction mixture was stirred for $12 \mathrm{~h}$ at $25^{\circ} \mathrm{C}$ and was quenched by the addition of saturated aqueous $\mathrm{NaHCO}_{3}$. The aqueous phase was extracted with $\mathrm{CH}_{2} \mathrm{Cl}_{2}(3 \times)$ and the combined organic extracts were dried $\left(\mathrm{MgSO}_{4}\right)$, filtered, and the filtrate was evaporated in vacuo. The residue was purified by flash chromatography (silica, 5\% $\mathrm{Et}_{3} \mathrm{~N} / \mathrm{h}$ exane) to afford pure $34(1.59 \mathrm{~g}, 77 \%)$ as a colorless oil: ${ }^{1} \mathrm{H} \mathrm{NMR}\left(\mathrm{CDCl}_{3}, 400 \mathrm{MHz}\right) \delta$ $6.64(\mathrm{~s}, 1 \mathrm{H}), 6.52(\mathrm{~d}, 1 \mathrm{H}, J=15.7 \mathrm{~Hz}), 6.31-6.40(\mathrm{~m}, 1 \mathrm{H}), 5.01(\mathrm{~s}, 2 \mathrm{H}), 3.80(\mathrm{~s}, 3 \mathrm{H}), 3.78$ (s, 3H), 3.59 (s, 3H), $2.11(\mathrm{~s}, 3 \mathrm{H}), 2.00(\mathrm{~d}, 2 \mathrm{H}, J=8.7 \mathrm{~Hz}), 1.49-1.55(\mathrm{~m}, 6 \mathrm{H}), 1.29-1.34(\mathrm{~m}, 6 \mathrm{H})$, 0.88-0.94 (m, 15H); ${ }^{13} \mathrm{C} \mathrm{NMR}\left(\mathrm{CDCl}_{3}, 125 \mathrm{MHz}\right) \delta 154.6,152.1,140.5,131.6,130.4,119.6$, 118.7, 102.0, 99.4, 60.4, 57.7, 55.7, 29.3, 27.5, 16.6, 13.7, 9.7, 9.0; IR (KBr) $v_{\max } 2924,1683$, $1631 \mathrm{~cm}^{-1}$; HRMS (ESI), $m / z$ calcd for $\mathrm{C}_{27} \mathrm{H}_{50} \mathrm{O}_{5} \mathrm{SnNa}\left(\mathrm{M}+\mathrm{Na}+\mathrm{CH}_{3} \mathrm{OH}\right)$ : 597.2572; found: 597.2544 .

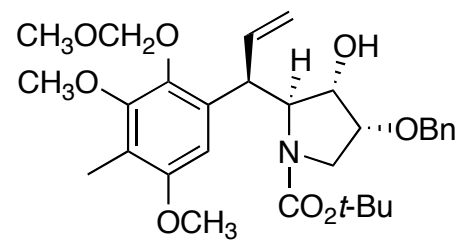

4-Benzyloxy-2-[1-(3,5-dimethoxy-2-methoxymethoxy-4methylphenyl) allyl]-3-hydroxypyrrolidine-1-carboxylic Acid tert-Butyl Ester (36). Boron trifluoride etherate $(0.38 \mathrm{~mL}, 3.0 \mathrm{mmol})$ was added over $30 \mathrm{~min}$ to a solution of $19(797.2 \mathrm{mg}$, $3.0 \mathrm{mmol})$ in $\mathrm{CH}_{2} \mathrm{Cl}_{2}(15 \mathrm{~mL})$ at $-78{ }^{\circ} \mathrm{C}$. The reaction mixture was stirred for $30 \mathrm{~min}$ at $-78{ }^{\circ} \mathrm{C}$ and stannane 34 (2.15 g, $3.98 \mathrm{mmol})$ was added. The reaction mixture was stirred for $30 \mathrm{~min}$ at $-78{ }^{\circ} \mathrm{C}$ and aqueous $\mathrm{K}_{2} \mathrm{HPO}_{4} / \mathrm{KH}_{2} \mathrm{PO}_{4}$ buffer $(1.0 \mathrm{M}, \mathrm{pH} 7,15 \mathrm{~mL})$ was added. The aqueous 
layer was extracted with EtOAc $(3 \times)$ and the combined organic extracts were dried $\left(\mathrm{Na}_{2} \mathrm{SO}_{4}\right)$, filtered, and the filtrate was evaporated in vacuo. The residue was purified by flash chromatography (silica, 15\% EtOAc/hexane) to afford pure $36(1.22 \mathrm{~g}, 75 \%)$ as a pale yellow oil: ${ }^{1} \mathrm{H}$ NMR $\left(\mathrm{CDCl}_{3}, 500 \mathrm{MHz}\right) \delta$ 6.56-6.45 (br, $\left.1 \mathrm{H}\right), 6.19-6.03(\mathrm{~m}, 1 \mathrm{H}), 5.05-4.87$ (m, 4H), 4.54-4.44 (m, 2H), 4.27-3.36 (br, 16H), 2.59-2.37 (br, 1H), 2.08 (br, 3H), 1.49-1.40 (br, 9H); ${ }^{13} \mathrm{C}$ NMR $\left(\mathrm{CDCl}_{3}, 125 \mathrm{MHz}\right) \delta 155.2,154.8,151.6,142.0,138.8,137.2,132.1,128.5,128.1,127.8$, 119.6, 115.8, 104.7, 99.6, 79.3, 71.9, 70.7, 67.8, 60.2, 57.6, 55.8, 48.5, 44.8, 29.7, 28.4, 8.8; HRMS (ESI), $m / z$ calcd for $\mathrm{C}_{30} \mathrm{H}_{41} \mathrm{NO}_{8} \mathrm{Na}$ : 566.2724 ; found: 566.2680 .

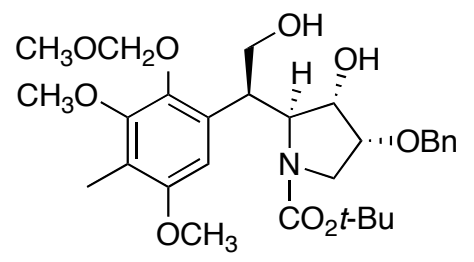

\section{4-Benzyloxy-2-[1-(3,5-dimethoxy-2-methoxymethoxy-4-} methylphenyl)-2-hydroxyethyl]-3-hydroxypyrrolidine-1-car-boxylic Acid tert-Butyl Ester (39). A stream of $\mathrm{O}_{3}$ in $\mathrm{O}_{2}$ was slowly bubbled into a solution of $\mathbf{3 6}$ (164 mg, $\left.0.30 \mathrm{mmol}\right)$ in $\mathrm{MeOH}(7 \mathrm{~mL})$ at $-78{ }^{\circ} \mathrm{C}$. The progress of the reaction was carefully monitored by TLC and $\mathrm{N}_{2}$ was bubbled into the reaction mixture for $30 \mathrm{~min}$ immediately after the reaction was judged complete. The reaction mixture was warmed to $0{ }^{\circ} \mathrm{C}$ and $\mathrm{NaBH}_{4}(330 \mathrm{mg}, 8.0 \mathrm{mmol})$ was added. The reaction mixture was stirred for $1 \mathrm{~h}$ at $0{ }^{\circ} \mathrm{C}$ and was evaporated in vacuo. The residue was purified by flash chromatography (silica, 20\% EtOAc/hexane) to afford pure 39 (92.5 mg, 62\%) as a colorless oil: ${ }^{1} \mathrm{H}$ NMR $\left(\mathrm{CDCl}_{3}, 500 \mathrm{MHz}\right) \delta$ 7.33-7.25 (m, 5H), $6.98(\mathrm{~s}, 1 \mathrm{H}), 4.95-4.90$ (app q, 2H), 4.58-4.52 (br, 1H), 4.52-4.43 (app q, 2H), 4.36-4.31 (m, 1H), 4.31-4.26 (br, 1H), 3.873.80 (br, 1H), 3.79 (br, 1H), 3.78 (s, 3H), $3.72(\mathrm{~s}, 3 \mathrm{H}), 3.65-3.58(\mathrm{~m}, 1 \mathrm{H}), 3.58-3.51(\mathrm{br}, 1 \mathrm{H})$, 3.48-3.42 (br, 1H), 3.36 (s, 3H), 2.97-2.91 (br d, 1H), 2.58-2.40 (br, 1H), 2.12 (s, 1H), 2.09 (s, 3H), 1.54-1.44 (br, 9H); $\left.{ }^{13} \mathrm{C} \mathrm{NMR} \mathrm{(CDCl} 3,125 \mathrm{MHz}\right) \delta$ 157.1, 154.7, 151.0, 141.8, 137.1, 132.0, $128.5,128.1,127.8,119.3,105.7,99.7,80.7,72.0,71.5,64.6,62.8,60.1,57.4,55.7,48.6,41.2$, 28.3, 8.8; HRMS (ESI), $m / z$ calcd for $\mathrm{C}_{29} \mathrm{H}_{41} \mathrm{NO}_{9} \mathrm{Na}: 570.2674$; found: 570.2668 . 


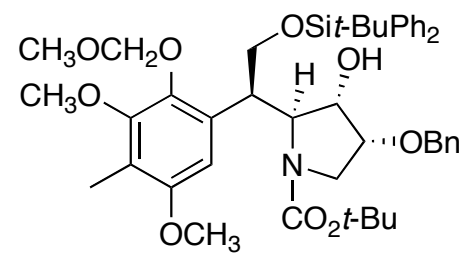

4-Benzyloxy-2-[2-(tert-butyldiphenylsilanyloxy)-1-(3,5dimethoxy-2-methoxymethoxy-4-methylphenyl)ethyl]-3-hydroxy-pyrrolidine-1-carboxylic Acid tert-Butyl Ester (40). tert-Butyldiphenylsilyl chloride (0.063 mL, $0.24 \mathrm{mmol})$ was added to a solution of $39(102 \mathrm{mg}, 0.19 \mathrm{mmol}), \mathrm{Et}_{3} \mathrm{~N}(0.034 \mathrm{~mL}, 0.24 \mathrm{mmol})$, and $4-$ (dimethylamino)pyridine $(10 \mathrm{mg})$ in $\mathrm{CH}_{2} \mathrm{Cl}_{2}(1 \mathrm{~mL})$ at $25^{\circ} \mathrm{C}$. The reaction mixture was stirred for $3 \mathrm{~h}$ at $25{ }^{\circ} \mathrm{C}$ and saturated aqueous $\mathrm{NaHCO}_{3}(1 \mathrm{~mL})$ was added. The aqueous layer was extracted with EtOAc $(3 \times)$ and the combined organic extracts were dried $\left(\mathrm{Na}_{2} \mathrm{SO}_{4}\right)$, filtered, and the filtrate was evaporated in vacuo. The residue was purified by flash chromatography (silica, 10\% EtOAc/hexane) to afford pure 40 (149 mg, 99\%) as a colorless oil: ${ }^{1} \mathrm{H} \mathrm{NMR}\left(\mathrm{CDCl}_{3}, 500\right.$ MHz) ठ 7.60-7.50 (m, 2H), 7.41-7.20 (m, 13H), 6.58-6.38 (br, 1H), 5.10-4.90 (m, 2H), 4.54-4.44 (m, 2H), 4.27-4.18 (br, 1H), 4.14-3.98 (br, 2H), 3.97-3.82 (br, 2H), 3.74 (s, 3H), 3.69-3.64 (br, $3 \mathrm{H}), 3.57-3.48$ (br, $4 \mathrm{H}), 3.45-3.32$ (br, $1 \mathrm{H}), 2.52-3.38$ (br, 1H), 2.20-2.12 (br, 3H), 1.44-1.18 (br, 9H), 1.00-0.86 (br, 9H); $\left.{ }^{13} \mathrm{C} \mathrm{NMR} \mathrm{(} \mathrm{CDCl}_{3}, 125 \mathrm{MHz}\right) \delta$ 155.4, 155.2, 154.7, 151.7, 151.6, 143.1, $142.8,137.3,135.6,135.5,133.8,133.6,133.5,133.4,131.9,129.6,129.5,129.3,128.5,128.1$, 127.7, 127.6, 127.4, 127.3, 119.4, 119.1, 104.2, 99.7, 99.6, 79.8, 79.4, 72.1, 71.1, 66.2, 65.8, $60.2,57.3,55.6,55.5,48.4,48.1,28.3,28.1,26.8,26.7,19.1,8.9$ (many are rotamers); HRMS (ESI), $m / z$ calcd for $\mathrm{C}_{45} \mathrm{H}_{59} \mathrm{O}_{9} \mathrm{NSiNa}$ : 808.3851; found: 808.3880 .

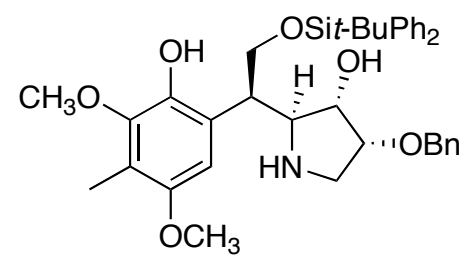

4-Benzyloxy-2-[2-(tert-butyldiphenylsilanyloxy)-1-(2-hydroxy3,5-dimethoxy-4-methylphenyl)ethyl]pyrrolidin-3-ol (41). Trifluoroacetic acid (1 mL) was added to a solution of $40(149 \mathrm{mg}, 0.19 \mathrm{mmol})$ in $\mathrm{CH}_{2} \mathrm{Cl}_{2}(1 \mathrm{~mL})$ at $25^{\circ} \mathrm{C}$. The reaction mixture was stirred for $10 \mathrm{~min}$ at $25^{\circ} \mathrm{C}$, cooled to $-40{ }^{\circ} \mathrm{C}$ and aqueous $\mathrm{K}_{2} \mathrm{HPO}_{4} / \mathrm{KH}_{2} \mathrm{PO}_{4}$ buffer $(1.0 \mathrm{M}$, $\mathrm{pH} 7,5 \mathrm{~mL})$ was added followed by the addition of $\mathrm{NaOH}(520 \mathrm{mg})$. The aqueous layer was extracted with EtOAc $(3 \times)$ and the combined organic extracts were dried $\left(\mathrm{Na}_{2} \mathrm{SO}_{4}\right)$, filtered, and the filtrate was evaporated in vacuo. The residue was purified by flash chromatography (silica, 
$50 \%$ EtOAc/hexane) to afford pure the pyrrolidine/phenol $41(97.1 \mathrm{mg}, 79 \%)$ as a pale yellow oil: ${ }^{1} \mathrm{H}$ NMR $\left(\mathrm{CDCl}_{3}, 500 \mathrm{MHz}\right)$ d $7.60(\mathrm{~m}, 3 \mathrm{H}), 7.44-7.23$ (m, 12H), 6.19 (s, 1H), $4.53(\mathrm{~s}, 2 \mathrm{H})$, $4.15(\mathrm{~m}, 1 \mathrm{H}), 3.94(\mathrm{~m}, 2 \mathrm{H}), 3.74(\mathrm{~s}, 3 \mathrm{H}), 3.69(\mathrm{~s}, 3 \mathrm{H}), 3.49(\mathrm{~m}, 1 \mathrm{H}), 3.25(\mathrm{~m}, 1 \mathrm{H}), 2.98(\mathrm{dd}, 1 \mathrm{H}$, $J=9.8,4.9 \mathrm{~Hz}$ ), 2.70 (d, 1H, $J=4.9 \mathrm{~Hz}), 2.49$ (dd, 1H, $J=9.8,4.9 \mathrm{~Hz}), 2.09$ (s, 3H), 0.96 (s, 9H); ${ }^{13} \mathrm{C}$ NMR $\left(\mathrm{CDCl}_{3}, 125 \mathrm{MHz}\right) \delta 153.4,150.9,143.7,137.4,135.6,134.7,133.6,133.2$, 129.7, 129.5, 128.5, 128.1, 127.7, 127.7, 127.5, 124.4, 119.5, 105.8, 79.1, 72.8, 72.1, 65.3, 64.1, $60.9,56.3,53.8,47.7,30.3,26.8,19.1,8.9$; HRMS (ESI), $m / z$ calcd for $\mathrm{C}_{38} \mathrm{H}_{47} \mathrm{NO}_{6} \mathrm{Si}+\mathrm{H}$ : 642.3245; found: 642.3195 .

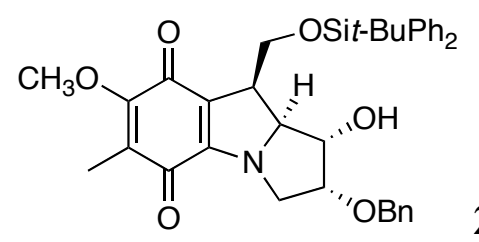

2-Benzyloxy-8-(tert-butyldiphenylsilanyloxymethyl)-1-hydroxy-6methoxy-5-methyl-2,3,8,8a-tetrahydro-1H-3a-azacyclopenta[a]-indene-4,7-dione (42). A solution of $\left(\mathrm{NH}_{4}\right)_{3} \mathrm{Ce}\left(\mathrm{NO}_{3}\right)_{6}(11.0 \mathrm{mg}, 8.7 \mu \mathrm{mol})$ in $\mathrm{H}_{2} \mathrm{O}(0.08 \mathrm{~mL})$ was added to a solution of the above pyrrolidine/phenol $(5.6 \mathrm{mg}, 8.7 \mu \mathrm{mol})$ in $\mathrm{CH}_{3} \mathrm{CN}(0.2 \mathrm{~mL})$ at $25^{\circ} \mathrm{C}$. The reaction mixture was stirred for $5 \mathrm{~min}$ at $25{ }^{\circ} \mathrm{C}$, cooled to $0{ }^{\circ} \mathrm{C}$ and saturated aqueous $\mathrm{NaHCO}_{3}(0.2 \mathrm{~mL})$ and EtOAc $(0.5 \mathrm{~mL})$ were added. The aqueous layer was extracted with EtOAc $(3 \times)$ and the combined organic extracts were dried $\left(\mathrm{Na}_{2} \mathrm{SO}_{4}\right)$, filtered, and the filtrate was evaporated in vacuo. The residue was purified by flash chromatography (silica, $5 \%$ EtOAc/hexane) to afford pure $48(1.1 \mathrm{mg}, 21 \%)$ as a pink oil: ${ }^{1} \mathrm{H} \mathrm{NMR}\left(\mathrm{CDCl}_{3}, 500 \mathrm{MHz}\right) \delta 7.74(\mathrm{~m}, 3 \mathrm{H}), 7.49-7.34(\mathrm{~m}$, $12 \mathrm{H}), 5.14(\mathrm{~m}, 1 \mathrm{H}), 5.04(\mathrm{~d}, 2 \mathrm{H}, J=3.7 \mathrm{~Hz}), 4.84(\mathrm{~d}, 1 \mathrm{H}, J=11.6 \mathrm{~Hz}), 4.70(\mathrm{~d}, 1 \mathrm{H}, J=12.2$ $\mathrm{Hz}), 4.47$ (dd, 1H, $J=12.2,7.3 \mathrm{~Hz}), 4.31$ (dd, $1 \mathrm{H}, J=12.2,7.3 \mathrm{~Hz}), 4.04$ (dd, 1H, $J=12.2,7.3$ Hz), 4.01 (s, 3H), 3.42 (dd, 1H, $J=14.6,7.3 \mathrm{~Hz}), 3.35$ (dd, $1 \mathrm{H}, J=14.0,6.7 \mathrm{~Hz}), 2.77$ (d, $1 \mathrm{H}, J=$ $1.8 \mathrm{~Hz}$ ), $2.13(\mathrm{~s}, 1 \mathrm{H}), 2.00$ (s, 3H), 1.15 (s, 9H); HRMS (ESI), $m / z$ calcd for $\mathrm{C}_{37} \mathrm{H}_{41} \mathrm{NO}_{6} \mathrm{SiNa}$ : 646.2601; found: 646.2655 .

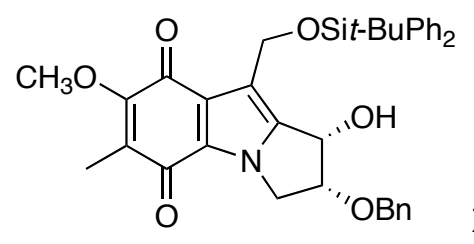

2-Benzyloxy-8-(tert-butyldiphenylsilanyloxy-methyl)-1-hydroxy6-methoxy-5-methyl-2,3-dihydro-1H-3a-azacyclopenta[a]in-dene-4,7-dione (43). A solution 
of $\mathrm{MeSO}_{2} \mathrm{Cl}(2.8 \mu 1,0.036 \mathrm{mmol})$ in $\mathrm{CH}_{2} \mathrm{Cl}_{2}(0.1 \mathrm{~mL})$ was slowly added to a solution of $42(7.4$ $\mathrm{mg}, 0.012 \mathrm{mmol})$ and $\mathrm{Et}_{3} \mathrm{~N}(8.4 \mu \mathrm{l}, 0.060 \mathrm{mmol})$ in $\mathrm{CH}_{2} \mathrm{Cl}_{2}(0.1 \mathrm{~mL})$ at $-20{ }^{\circ} \mathrm{C}$. The reaction mixture was stirred for $3 \mathrm{~h}$ at $25^{\circ} \mathrm{C}$ and aqueous $\mathrm{K}_{2} \mathrm{HPO}_{4} / \mathrm{KH}_{2} \mathrm{PO}_{4}$ buffer $(1.0 \mathrm{M}$, pH 7, $0.2 \mathrm{~mL})$ was added. The aqueous layer was extracted with EtOAc $(3 \times)$ and the combined organic extracts were dried $\left(\mathrm{Na}_{2} \mathrm{SO}_{4}\right)$, filtered, and the filtrate was evaporated in vacuo. The residue was purified by flash chromatography (silica, 5\% EtOAc/hexane) to afford $\mathbf{4 3}$ with some contamination of $\mathbf{4 2}$ (3.9 mg, 56\%) as a pink oil: ${ }^{1} \mathrm{H} \mathrm{NMR}\left(\mathrm{CDCl}_{3}, 500 \mathrm{MHz}\right) \delta 7.65(\mathrm{~m}, 3 \mathrm{H}), 7.43-7.26(\mathrm{~m}, 12 \mathrm{H})$, $5.21(\mathrm{~s}, 1 \mathrm{H}), 5.07$ (d, 1H, $J=15.3 \mathrm{~Hz}), 4.95(\mathrm{~d}, 1 \mathrm{H}, J=15.0 \mathrm{~Hz}), 4.75(\mathrm{~d}, 1 \mathrm{H}, J=11.9 \mathrm{~Hz}), 4.61$ (d, 1H, $J=11.9 \mathrm{~Hz}), 4.54$ (m, 1H), 4.44 (dd, 1H, $J=13.1,6.7 \mathrm{~Hz}), 4.42$ (dd, 1H, $J=13.1,4.0$ $\mathrm{Hz}$ ), 3.97 (s, 3H), 3.35 (d, 1H, $J=1.2 \mathrm{~Hz}$ ), 1.94 (s, 3H), 1.11 (s, 9H); HRMS (ESI), $m / z$ calcd for $\mathrm{C}_{37} \mathrm{H}_{39} \mathrm{NO}_{6} \mathrm{SiNa}$ : 644.2445; found: 644.2418 .

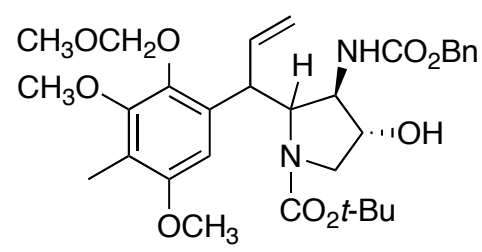

3 - Benzylox ycarbonylamino-2-[1-(3,5-dimethoxy-2 methoxymethoxy-4-methylphenyl)allyl]-4-hydroxy-pyrrolidine-1-carboxylic Acid tert-Butyl Ester (46). Boron trifluoride etherate $(0.42 \mathrm{~mL}, 3.00 \mathrm{mmol})$ was slowly added to a solution of 37 (898.6 mg, $2.55 \mathrm{mmol})$ and $34(1.79 \mathrm{~g}, 3.32 \mathrm{mmol})$ in $\mathrm{CH}_{2} \mathrm{Cl}_{2}(12 \mathrm{~mL})$ at $-78{ }^{\circ} \mathrm{C}$. The reaction mixture was stirred for $30 \mathrm{~min}$ at $-78{ }^{\circ} \mathrm{C}$ and aqueous $\mathrm{K}_{2} \mathrm{HPO}_{4} / \mathrm{KH}_{2} \mathrm{PO}_{4}$ buffer $(1.0 \mathrm{M}$, pH 7, 15 $\mathrm{mL}$ ) was added. The aqueous layer was extracted with EtOAc $(3 \times)$ and the combined organic extracts were dried $\left(\mathrm{Na}_{2} \mathrm{SO}_{4}\right)$, filtered, and the filtrate was evaporated in vacuo. The residue was purified by flash chromatography (silica, 25\% EtOAc/hexane) to afford pure 46 ( $838.0 \mathrm{mg}, 56 \%)$ as a pale yellow oil: ${ }^{1} \mathrm{H}$ NMR $\left(\mathrm{CDCl}_{3}, 500 \mathrm{MHz}\right) \delta 7.30(\mathrm{~m}, 5 \mathrm{H}), 6.54-6.50(\mathrm{br}, 1 \mathrm{H}), 6.17(\mathrm{~m}$, 1H), 5.24 (m, 2H), 5.29-4.96 (br, $6 \mathrm{H}), 4.69-3.16$ (br, $15 \mathrm{H}), 2.10-2.03$ (br, 3H), 1.44 (br, 9H); ${ }^{13} \mathrm{C} \mathrm{NMR}\left(\mathrm{CDCl}_{3}, 125 \mathrm{MHz}\right) \delta 153.3,151.8,151.6,141.7,135.9,135.8,128.53,128.5,128.2$, 128.0, 127.8, 119.8, 119.4, 105.7, 99.6, 99.6, 80.3, 79.8, 71.8, 67.3, 67.1, 66.9, 65.9, 60.4, 60.2, $57.6,55.7,52.7,52.1,51.7,28.3,8.9,8.7$ (mixture of diastereomers; some peaks belong to rotamers); HRMS (ESI), $m / z$ calcd for $\mathrm{C}_{31} \mathrm{H}_{42} \mathrm{~N}_{2} \mathrm{O}_{9} \mathrm{Na}$ : 609.2783; found: 609.2766 . 


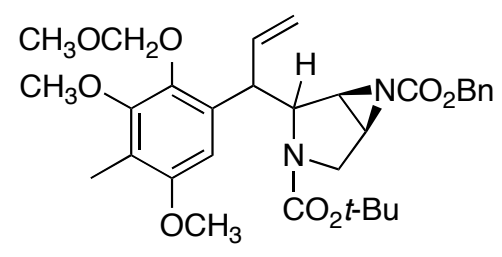

\section{2-[1-(3,5-Dimethoxy-2-methoxymethoxy-4-methyl} phenyl)allyl]-3,6-diazabicyclo[3.1.0]hexane-3,6-dicarboxylic Acid 6-Benzyl Ester 3-tertButyl Ester (47). Diisopropyl azodicarboxylate $(0.039 \mathrm{~mL}, 0.20 \mathrm{mmol})$ was slowly added to a solution of $46(118.2 \mathrm{mg}, 0.20 \mathrm{mmol})$ and $\mathrm{PPh}_{3}(104.8 \mathrm{mg}, 0.40 \mathrm{mmol})$ in THF $(10 \mathrm{~mL})$ at 25 ${ }^{\circ} \mathrm{C}$. The reaction mixture was stirred for $1 \mathrm{~h}$ at $25{ }^{\circ} \mathrm{C}$ and aqueous $\mathrm{K}_{2} \mathrm{HPO}_{4} / \mathrm{KH}_{2} \mathrm{PO}_{4}$ buffer $(1.0$ $\mathrm{M}, \mathrm{pH} 7,5 \mathrm{~mL})$ was added. The aqueous layer was extracted with EtOAc $(3 \times)$ and the combined organic extracts were dried $\left(\mathrm{Na}_{2} \mathrm{SO}_{4}\right)$, filtered, and the filtrate was evaporated in vacuo. The residue was purified by flash chromatography (silica, 10\% EtOAc/hexane) to afford pure 47 (89.7 mg, 79\%) as a pale yellow oil: ${ }^{1} \mathrm{H}$ NMR $\left(\mathrm{CDCl}_{3}, 500 \mathrm{MHz}\right) \delta 7.33(\mathrm{~m}, 5 \mathrm{H}), 6.57-6.46(\mathrm{br}$, 1H), 6.23 (br, 1H), 5.28-4.94 (br, 8 H), 4.42-3.31 (br, $13 \mathrm{H}), 3.15-2.63$ (br, 2H), 2.08-2.00 (br, $3 \mathrm{H}), 1.47$ (br, 9H); ${ }^{13} \mathrm{C} \mathrm{NMR}\left(\mathrm{CDCl}_{3}, 125 \mathrm{MHz}\right) \delta 158.7,152.3,152.0,141.9,136.2,136.0$, 129.6, 129.2, 128.5, 128.0, 127.7, 119.4, 119.0, 106.4, 98.7, 98.6, 80.9, 80.7, 67.0, 66.9, 66.5, $66.4,65.9,61.4,61.3,58.3,54.6,52.0,51.9,51.7,45.0,44.6,39.4,39.4,38.8,28.8,8.7,8.5$ (mixture of diastereomers; some peaks belong to rotamers); HRMS (ESI), $\mathrm{m} / \mathrm{z}$ calcd for $\mathrm{C}_{31} \mathrm{H}_{40} \mathrm{~N}_{2} \mathrm{O}_{8} \mathrm{Na}$ : 591.2683; found: 591.2697.

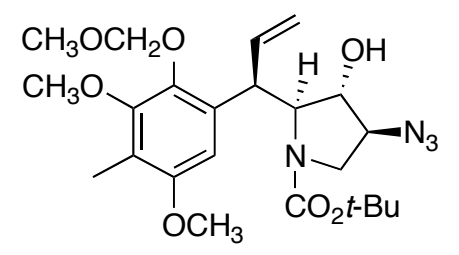

Azidoalcohol 49. Borontrifluoride etherate $(0.58 \mathrm{~mL}, 4.58 \mathrm{mmol})$ was added to a solution of azide $22(1.00 \mathrm{~g}, 3.52 \mathrm{mmol})$ and stannane $34(2.48 \mathrm{~g}, 4.58 \mathrm{mmol})$ in $\mathrm{CH}_{2} \mathrm{Cl}_{2}(15 \mathrm{~mL})$ at $-40{ }^{\circ} \mathrm{C}$ and the reaction mixture was stirred for $2 \mathrm{~h}$ at this temperature. The reaction was quenched by the addition of saturated aqueous $\mathrm{Na}_{2} \mathrm{CO}_{3}$ and was extracted three times with $\mathrm{CH}_{2} \mathrm{Cl}_{2}$. The combined organic extracts were dried $\left(\mathrm{MgSO}_{4}\right)$ and evaporated in vacuo. The residue was purified by a short-column flash chromatography (silica, 35\% EtOAc/hexane) to give azidoalcohol 49 (1.26 g, 73\%) as a colorless oil, and the recovered azide 22 (120 mg, 12\%). Crude NMR showed two diastereoisomers in a 7:3 ratio, inseparable by flash chromatography. The mixture was characterized: ${ }^{1} \mathrm{H}$ NMR $\left(\mathrm{CDCl}_{3}, 500 \mathrm{MHz}, 60{ }^{\circ} \mathrm{C}\right) \delta 5.88-5.70(\mathrm{br}, 1 \mathrm{H}), 4.50$ 
(br t, 1H), 4.02 (br, 1H), 3.87-3.73 (br, 1H), 3.07 (br t, 1H), 2.45-2.37 (br, 1H), 1.46 (s, 3H), 1.43 (s, 9H), 1.33 (s, 3H); IR (KBr) $v_{\max } 3408,3078,2937,2104,1674,1605,1584 \mathrm{~cm}^{-1}$; HRMS (ESI), $m / z$ calcd for $\mathrm{C}_{23} \mathrm{H}_{34} \mathrm{~N}_{4} \mathrm{O}_{7} \mathrm{Na}$ : 501.1825; found: 501.2268.

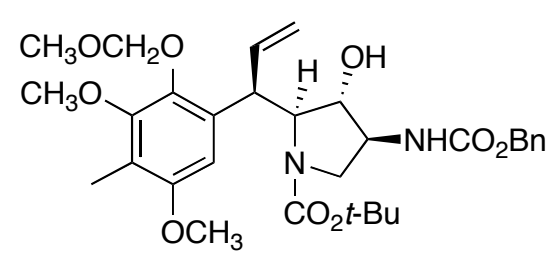

Carbamate Alcohol 50. A solution of azidoalcohol 49 (1.41 g, $2.94 \mathrm{mmol})$ in $\mathrm{CH}_{3} \mathrm{CN}(20 \mathrm{~mL})$ was added to a solution of $\mathrm{SnCl}_{2}(937 \mathrm{mg}, 4.71 \mathrm{mmol})$, thiophenol $(1.45 \mathrm{~mL}, 14.2 \mathrm{mmol})$ and $\mathrm{Et}_{3} \mathrm{~N}(1.97 \mathrm{~mL}, 14.2 \mathrm{mmol})$ in $\mathrm{CH}_{3} \mathrm{CN}(20 \mathrm{~mL})$ at $0{ }^{\circ} \mathrm{C}$. The reaction mixture was stirred for $1 \mathrm{~h}$ and additional thiophenol $(0.30 \mathrm{~mL}, 2.94 \mathrm{mmol})$ was added. After an additional $1 \mathrm{~h}$, the mixture was diluted with $\mathrm{CH}_{2} \mathrm{Cl}_{2}(100 \mathrm{~mL})$ and washed with $2 \mathrm{~N} \mathrm{NaOH}$ solution $(2 \mathrm{x})$. The aqueous phase was extracted with $\mathrm{CH}_{2} \mathrm{Cl}_{2}(3 \times)$. The combined organic extracts were dried $\left(\mathrm{MgSO}_{4}\right)$ and evaporated under reduced pressure. The residual yellow oil was diluted with $\mathrm{CH}_{2} \mathrm{Cl}_{2}(50 \mathrm{~mL})$ and was treated with $\mathrm{Et}_{3} \mathrm{~N}(0.82 \mathrm{~mL}, 5.90 \mathrm{mmol})$ and benzyl chloroformate $(0.42 \mathrm{~mL}, 2.94 \mathrm{mmol})$ at $0{ }^{\circ} \mathrm{C}$. The reaction mixture was stirred $3 \mathrm{~h}$ at room temperature and was quenched by the addition of saturated aqueous $\mathrm{NaHCO}_{3}$. The aqueous phase was extracted with $\mathrm{CH}_{2} \mathrm{Cl}_{2}(3 \times)$ and the organic phase was dried $\left(\mathrm{MgSO}_{4}\right)$ and concentrated under reduced pressure. The residue was purified by flash chromatography (silica, $30 \% \mathrm{Et}_{2} \mathrm{O} /$ toluene) to give the major diastereoisomer 50 (933 $\left.\mathrm{mg}, 54 \%\right)$ and the minor diastereoisomer 50 (363 mg, 21\%): IR (KBr) $v_{\max } 3356,2929,1694,1607,1589 \mathrm{~cm}^{-1}$.

The major isomer of $\mathbf{5 0}$ was characterized: ${ }^{1} \mathrm{H}$ NMR $\left(\mathrm{CDCl}_{3}, 500 \mathrm{MHz}, 60{ }^{\circ} \mathrm{C}\right) \delta$ 7.28-7.37 (m, $5 \mathrm{H}), 6.56(\mathrm{~s}, 1 \mathrm{H}), 6.11-6.19(\mathrm{~m}, 1 \mathrm{H}), 5.74(\mathrm{br} \mathrm{s}, 1 \mathrm{H}), 4.99-5.13(\mathrm{~m}, 6 \mathrm{H}), 4.18-4.26(\mathrm{~m}, 2 \mathrm{H})$, 3.99-4.02 (m, 1H), 3.93 (app t, 1H, $J=9.1 \mathrm{~Hz}), 3.80$ (s, 1H), 3.75 (s, 3H), 3.72 (s, 3H), 3.44 (s, $3 \mathrm{H}), 3.06-3.10(\mathrm{~m}, 1 \mathrm{H}), 2.51(\mathrm{~s}, 1 \mathrm{H}), 2.11(\mathrm{~s}, 3 \mathrm{H}), 1.48(\mathrm{~s}, 9 \mathrm{H}) ;{ }^{13} \mathrm{C} \mathrm{NMR}\left(\mathrm{CDCl}_{3}, 125 \mathrm{MHz}, 60\right.$ $\left.{ }^{\circ} \mathrm{C}\right) \delta 156.4,155.4,155.0,152.1,141.8,138.9,136.7,132.1,128.6,128.3,128.2,120.2,116.2$, 105.5, 100.1, 80.0, 79.5, 69.3, 67.1, 60.3, 58.5, 57.8, 56.0, 51.8, 45.6, 28.6, 8.9; HRMS (ESI), $\mathrm{m} / \mathrm{z}$ calcd for $\mathrm{C}_{31} \mathrm{H}_{42} \mathrm{~N}_{2} \mathrm{O}_{9} \mathrm{Na}$ : 609.2783; found: 609.2749.

The minor isomer of $\mathbf{5 0}$ was characterized: ${ }^{1} \mathrm{H}$ NMR $\left(\mathrm{CDCl}_{3}, 400 \mathrm{MHz}\right) \delta 7.30-7.36(\mathrm{~m}, 5 \mathrm{H})$, 6.55 (s, 1H), 6.10-6.19 (m, 1H), 5.63 (br s, 1H), 4.95-5.22 (m, 6H), 3.98-4.23 (m, 5H), 3.78-3.81 
(m, 1H), $3.78(\mathrm{~s}, 3 \mathrm{H}), 3.72(\mathrm{~s}, 3 \mathrm{H}),(\mathrm{m}, 1 \mathrm{H}), 3.05$ (br s, 1H), 2.08 (s, 3H), 1.26 (s, 9H); HRMS (ESI), $m / z$ calcd for $\mathrm{C}_{31} \mathrm{H}_{42} \mathrm{~N}_{2} \mathrm{O}_{9} \mathrm{Na}$ : 609.2783; found: 609.2769 .

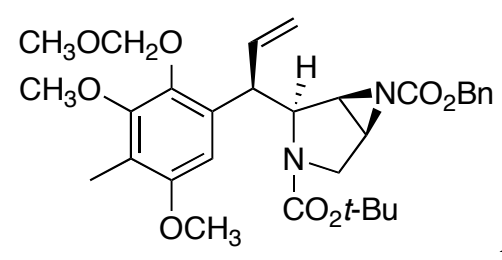
was added to a solution of compound $\mathbf{5 0}(426 \mathrm{mg}, 0.727 \mathrm{mmol})$ and $\mathrm{Ph}_{3} \mathrm{P}(381 \mathrm{mg}, 1.45 \mathrm{mmol})$ in THF $(15 \mathrm{~mL})$ at $0{ }^{\circ} \mathrm{C}$. The mixture was stirred for $2 \mathrm{~h}$ at room temperature and the volatiles were removed under reduced pressure. The residue was taken up in ether and the white precipitate in filtered. The filtrate was concentrated in vacuo, and the residue was purified by flash chromatography (silica, 30\% EtOAc/hexane) to give aziridine 51 (336 mg, 81\%): ${ }^{1} \mathrm{H}$ NMR $\left(\mathrm{CDCl}_{3}, 400 \mathrm{MHz}\right) \delta$ 7.27-7.40 (m, 5H), $6.73(\mathrm{~s}, 1 \mathrm{H}), 6.19-6.28(\mathrm{~m}, 1 \mathrm{H}), 5.16(\mathrm{~d}, 1 \mathrm{H}, J=12.3$ Hz), 4.96-5.05 (m, 5H), 4.63 (app d, 1H, $J=9.5 \mathrm{~Hz}), 4.21(\mathrm{~m}, 1 \mathrm{H}), 3.82(\mathrm{~s}, 3 \mathrm{H}), 3.77-3.82(\mathrm{~m}$, $1 \mathrm{H}), 3.77(\mathrm{~s}, 3 \mathrm{H}), 3.61-3.65(\mathrm{~m}, 1 \mathrm{H}), 3.61(\mathrm{~s}, 3 \mathrm{H}), 3.31(\mathrm{~s}, 2 \mathrm{H}), 2.17(\mathrm{~s}, 3 \mathrm{H}), 1.52(\mathrm{~s}, 9 \mathrm{H}) ;{ }^{13} \mathrm{C}$ NMR $\left(\mathrm{CDCl}_{3}, 100 \mathrm{MHz}, 6{ }^{\circ} \mathrm{C}\right) \delta 161.9,155.2,154.2,151.9,142.0,140.3,135.7,131.9,128.4$, 128.2, 127.9, 119.0, 114.6, 105.7, 99.0, 79.9, 67.9, 61.4, 60.0, 57.3, 55.6, 50.1, 46.9, 44.3, 28.2, 8.8; IR (KBr) $v_{\max } 2934,1728,1698 \mathrm{~cm}^{-1}$; HRMS (ESI), $m / z$ calcd for $\mathrm{C}_{31} \mathrm{H}_{40} \mathrm{~N}_{2} \mathrm{O}_{8} \mathrm{Na}: 591.2677$; found: 591.2718 .

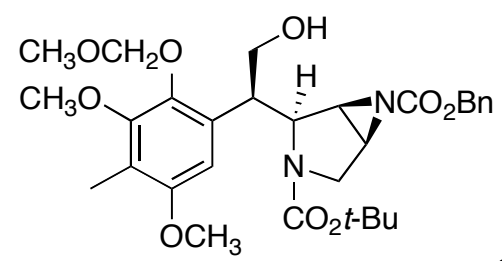

Aziridinoalcohol 52. A stream of $\mathrm{O}_{3}$ in $\mathrm{O}_{2}$ was slowly bubbled into a solution of $51(390 \mathrm{mg}, 0.687 \mathrm{mmol})$ in $\mathrm{MeOH}(60 \mathrm{~mL})$ and $\mathrm{CH}_{2} \mathrm{Cl}_{2}(18 \mathrm{~mL})$ at $-78{ }^{\circ} \mathrm{C}$. The progress of the reaction was carefully monitored by TLC and $\mathrm{N}_{2}$ was bubbled into the reaction mixture for $30 \mathrm{~min}$ immediately after the reaction was judged complete. The reaction mixture was warmed to $0{ }^{\circ} \mathrm{C}$ and $\mathrm{NaBH}_{4}(261 \mathrm{mg}, 6.87 \mathrm{mmol})$ was added. The reaction mixture was stirred for $4 \mathrm{~h}$ at $0{ }^{\circ} \mathrm{C}$ and was quenched with water. The aqueous phase was extracted with $\mathrm{CH}_{2} \mathrm{Cl}_{2}(3 \times)$, dried $\left(\mathrm{MgSO}_{4}\right)$, and concentrated under reduced pressure. The residue was purified by flash chromatography (silica, 30\% EtOAc/hexane) to afford $\mathbf{5 2}(247 \mathrm{mg}, 63 \%)$ as a colorless 
oil: ${ }^{1} \mathrm{H}$ NMR $\left(\mathrm{CDCl}_{3}, 400 \mathrm{MHz}\right) \delta$ 7.29-7.34 (m, 3H), $7.12(\mathrm{~s}, 2 \mathrm{H}), 6.78(\mathrm{~s}, 1 \mathrm{H}), 5.08(\mathrm{~d}, 1 \mathrm{H}, J=$ 12.4 Hz), 4.96-4.99 (m, 2H), 4.85 (d, 1H, $J=12.4$ Hz), 4.65-4.68 (m, 1H), 4.27 (s br, 1H), 3.85 $(\mathrm{s}, 3 \mathrm{H}), 3.80-3.86(\mathrm{~m}, 1 \mathrm{H}), 3.71(\mathrm{~s}, 3 \mathrm{H}), 3.65-3.71(\mathrm{~m}, 1 \mathrm{H}), 3.60(\mathrm{~d}, 1 \mathrm{H}, J=12.6 \mathrm{~Hz}), 3.55$ (s, $3 \mathrm{H}), 3.28-3.31(\mathrm{~m}, 2 \mathrm{H}), 2.13(\mathrm{~s}, 3 \mathrm{H}), 1.51(\mathrm{~s}, 9 \mathrm{H}) ;{ }^{13} \mathrm{C} \mathrm{NMR}\left(\mathrm{CDCl}_{3}, 125 \mathrm{MHz}, 60{ }^{\circ} \mathrm{C}\right) \delta 161.9$, $157.1,154.3,151.7,142.2,135.7,131.8,128.5,128.2,127.8,119.2$, 105.9, 99.2, 81.2, 68.0, 63.9, 60.1, 58.5, 57.2, 55.8, 50.5, 47.4, 44.1, 42.5, 28.4, 9.0; IR (KBr) v $\max 3446,3064,2937,1729$, $1677 \mathrm{~cm}^{-1}$; HRMS (ESI), $m / z$ calcd for $\mathrm{C}_{30} \mathrm{H}_{40} \mathrm{~N}_{2} \mathrm{O}_{9} \mathrm{Na}$ : 595.2632; found: 595.2628.

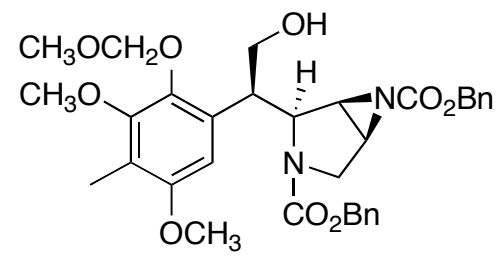

Bis-benzylcarbamate 53. Trimethylsilyl trifluoromethanesulfonate $(84 \mu \mathrm{L}, 0.47 \mathrm{mmol}$ ) was added to a solution of 2,6-di-tertbutylpyridine (122 $\mu \mathrm{L}, 0.544 \mathrm{mmol})$ and carbamate $52(89.0 \mathrm{mg}, 0.156 \mathrm{mmol})$ in $\mathrm{CH}_{2} \mathrm{Cl}_{2}(3.5$ $\mathrm{mL}$ ) at $0{ }^{\circ} \mathrm{C}$. The reaction mixture was stirred at $0{ }^{\circ} \mathrm{C}$ for $2 \mathrm{~h}$ when a buffered solution of pyridinium fluoride ( $1 \mathrm{~mL} \mathrm{HF} / 3 \mathrm{~mL}$ pyridine, $1.55 \mathrm{mmol}$ ) was added and the mixture was stirred for $15 \mathrm{~min}$ at $0{ }^{\circ} \mathrm{C}$. The mixture was washed with aqueous $3 \mathrm{~N} \mathrm{NaOH}$ and the aqueous phase was extracted $\mathrm{CH}_{2} \mathrm{Cl}_{2}(3 \times)$. The combined organic extracts were dried $\left(\mathrm{MgSO}_{4}\right)$, and the solvent was removed in vacuo. The residue was dissolved in $\mathrm{CH}_{2} \mathrm{Cl}_{2}(4 \mathrm{~mL})$ at $0{ }^{\circ} \mathrm{C}$ and treated sequentially with $\mathrm{Et}_{3} \mathrm{~N}(32.0 \mu \mathrm{L}, 0.233 \mathrm{mmol})$ and benzyl chloroformate $(24.0 \mu \mathrm{L}, 0.171 \mathrm{mmol})$. The reaction mixture was allowed to warm to room temperature, and was stirred $3 \mathrm{~h}$ at this temperature. The reaction was quenched by the addition of saturated aqueous $\mathrm{NaHCO}_{3}$, and the aqueous phase was extracted with $\mathrm{CH}_{2} \mathrm{Cl}_{2}(3 \mathrm{x})$. The combined organic extracts were dried $\left(\mathrm{MgSO}_{4}\right)$, and the solvent was removed in vacuo. The residue was purified by flash chromatography (silica, $40 \%$ EtOAc/hexane) to afford pure $\mathbf{5 3}(56.5 \mathrm{mg}, 60 \%):{ }^{1} \mathrm{H} \mathrm{NMR}\left(\mathrm{CDCl}_{3}, 500 \mathrm{MHz}, 60{ }^{\circ} \mathrm{C}\right) \delta 7.27-$ 7.39 (m, 8H), 7.06 (s br, 2H), 6.37 (s, 1H), 5.47 (s br, 1H), 5.14-5.20 (m, 2H), 4.91 (d, 2H, $J=$ $12.2 \mathrm{~Hz}$ ), 4.72 (s br, 1H), 4.69-4.70 (m, 2H), 4.38 (s br, 1H), 4.23 (s br, 2H), 4.15 (t, 1H, J = 8.2 Hz), 3.81-3.84 (m, 2H), 3.73 (s br, 6H), 3.54 (s br, 3H), 3.04 (t, 1H, $J=10.4 \mathrm{~Hz}), 2.15$ (s, 3H); ${ }^{13} \mathrm{C} \mathrm{NMR}\left(\mathrm{CDCl}_{3}, 125 \mathrm{MHz}, 60{ }^{\circ} \mathrm{C}\right) \delta 156.1,154.7,152.0,143.4,136.7,136.5,128.7,128.5$, $128.3,128.3,128.1,128.1,127.3,120.2,105.4,100.0,83.1,82.4,74.0,67.2,64.7,60.2,57.4$, 
56.1, 53.7, 51.7, 43.9, 9.0; IR (KBr) $v_{\max } 3430,3334,2941,1710 \mathrm{~cm}^{-1}$; HRMS (ESI), $m / z$ calcd for $\mathrm{C}_{33} \mathrm{H}_{38} \mathrm{~N}_{2} \mathrm{O}_{9} \mathrm{Na}$ : 629.2470; found: 629.2477 .

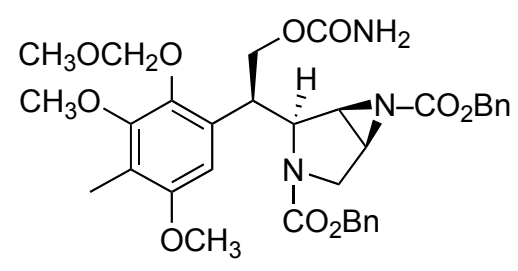

Carbamate 54. A solution of alcohol $53(70.1 \mathrm{mg}, 0.116 \mathrm{mmol})$ in $\mathrm{CH}_{2} \mathrm{Cl}_{2}(1 \mathrm{~mL})$ was added trichloroacetyl isocyanate $(83 \mu \mathrm{L}, 0.693 \mathrm{mmol})$. The resulting mixture was stirred for $12 \mathrm{~h}$ at $65^{\circ} \mathrm{C}$ in a sealed tube. After cooling to room temperature, another portion of trichloroacetyl isocyanate ( $83 \mu \mathrm{L}, 0.693 \mathrm{mmol}$ ) was added and the solution was stirred for 24 $\mathrm{h}$ at $65^{\circ} \mathrm{C}$. Then, the mixture was carefully deposited on a short column of neutral alumina that was pre-wetted with $\mathrm{CH}_{2} \mathrm{Cl}_{2}$. After 30 min on standing, the mixture was mixture was eluted with EtOAc. The crude was purified by flash chromatography (silica, $60 \%$ EtOAc/hexane) to afford pure $54(64.5 \mathrm{mg}, 86 \%)$ as a colorless oil: ${ }^{1} \mathrm{H} \mathrm{NMR}\left(\mathrm{CDCl}_{3}, 500 \mathrm{MHz}, 50{ }^{\circ} \mathrm{C}\right) \delta$ 7.33-7.41 (m, 5H), $7.22(\mathrm{~s} \mathrm{br}, 3 \mathrm{H}), 6.95(\mathrm{~s} \mathrm{br}, 2 \mathrm{H}), 6.19(\mathrm{~s}, 1 \mathrm{H}), 5.31$ (d, 1H, J=11.9 Hz), $5.22(\mathrm{~s}, 1 \mathrm{H}), 5.21(\mathrm{~d}$, $1 \mathrm{H}, J=11.9 \mathrm{~Hz}), 4.81(\mathrm{~m}, 4 \mathrm{H}), 4.61(\mathrm{~s} \mathrm{br}, 1 \mathrm{H}), 4.10-4.20(\mathrm{~m}, 4 \mathrm{H}), 3.93(\mathrm{~m}, 1 \mathrm{H}), 3.46-3.79(\mathrm{~m}$, $10 \mathrm{H}), 2.11(\mathrm{~s}, 3 \mathrm{H}) .{ }^{13} \mathrm{C} \mathrm{NMR}\left(\mathrm{CDCl}_{3}, 125 \mathrm{MHz}, 50{ }^{\circ} \mathrm{C}\right) \delta 156.3,155.5,154.6,154.4,151.7$, 142.9, 136.2, 134.7, 129.0, 128.9, 128.3, 128.0, 127.9, 127.0, 119.8, 105.5, 99.6, 83.0, 73.7, 69.3, 67.0, 63.7, 60.1, 57.5, 57.2, 56.1, 53.4, 48.1, 43.3, 8.9. IR (KBr) $v_{\max } 3430,3337,2954,1720$, $1698 \mathrm{~cm}^{-1}$; HRMS (ESI), m/e calcd for $\mathrm{C}_{34} \mathrm{H}_{39} \mathrm{~N}_{3} \mathrm{O}_{10} \mathrm{Na}$ : 672.2528; found: 672.2520 .<smiles>COC1=C(C)C(=O)C(C(COC(N)=O)[C@@H]2CC3C2N3C(=O)OCc2ccccc2)=CC1=O</smiles>

Quinone 55. A solution of ceric ammonium nitrate (128 mg, 0.234 mmol) in $\mathrm{H}_{2} \mathrm{O}(0.6 \mathrm{~mL})$ was added to a room temperature solution of compound 54 (38 $\mathrm{mg}$, $0.059 \mathrm{mmol})$ in $\mathrm{CH}_{3} \mathrm{CN}(2.5 \mathrm{~mL})$. The mixture was stirred $10 \mathrm{~min}$ at this temperature and was diluted with $\mathrm{CH}_{2} \mathrm{Cl}_{2}$ and washed with water. The aqueous phase was extracted with $\mathrm{CH}_{2} \mathrm{Cl}_{2}$ (3 $x)$, and the organic phase was dried $\left(\mathrm{MgSO}_{4}\right)$, and concentrated under reduced pressure. The residue was purified by flash chromatography (60\% EtOAc/hexane) to give 55 (32.7 $\mathrm{mg}, 95 \%)$ : ${ }^{1} \mathrm{H}$ NMR ( $\left.\mathrm{CDCl}_{3}, 500 \mathrm{MHz}\right)$ 8 7.41-7.45 (m, 5H), 7.26-7.30 (m, 3H), 7.14 (br s, 2H), 5.76 (s, 
1H), $5.24(\mathrm{~m}, 2 \mathrm{H}), 4.99$ (d, 1H, $J=12.4 \mathrm{~Hz}), 4.86-4.89$ (m, 1H), $4.82(\mathrm{~d}, 1 \mathrm{H}, J=12.4 \mathrm{~Hz}), 4.75$ (t, $1 \mathrm{H}, J=5.2 \mathrm{~Hz}), 4.56(\mathrm{t}, 1 \mathrm{H}, J=5.4 \mathrm{~Hz}), 4.05(\mathrm{~s}, 3 \mathrm{H}), 3.91-4.00(\mathrm{~m}, 2 \mathrm{H}), 3.65-3.67(\mathrm{~m}, 2 \mathrm{H})$, $3.38(\mathrm{~m}, 1 \mathrm{H}), 1.83(\mathrm{~s}, 3 \mathrm{H}) ;{ }^{13} \mathrm{C} \mathrm{NMR}\left(\mathrm{CDCl}_{3}, 125 \mathrm{MHz}\right) \delta$ 187.7, 181.6, 157.6, 156.1, 155.3, 154.9, 142.4, 136.5, 134.3, 130.3, 129.6, 129.2, 129.1, 128.7, 128.2, 127.5, 126.9, 82.1, 69.7, 69.2, 67.1, 63.5, 60.6, 56.5, 47.7, 43.6, 8.4; IR (KBr) $v_{\max } 3437,3331,2921,1726,1695,1654$, $1610 \mathrm{~cm}^{-1}$; HRMS (ESI), $\mathrm{m} / z$ calcd for $\mathrm{C}_{31} \mathrm{H}_{31} \mathrm{~N}_{3} \mathrm{O}_{9} \mathrm{Na}$ : 612.1953; found: 612.1950 .

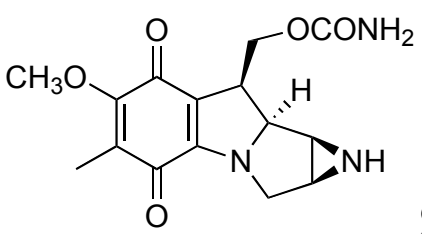

9a-Desmethoxy Mitomycin A (1). A solution of carbamate 55 (15 mg, $0.027 \mathrm{mmol})$ in $\mathrm{MeOH}\left(2 \mathrm{~mL}\right.$ ) was stirred with $\mathrm{Pd} / \mathrm{C}$ (catalytic) under an atmosphere of $\mathrm{H}_{2}$ (balloon) at room temperature for $3 \mathrm{~h}$. Following filtration of the catalyst first through Celite then through a 45 micron filter, the solution was vigorously stirred open to the air for $4 \mathrm{~h}$. The volatiles were removed under reduced pressure and the residue was purified by preparative TLC $\left(10 \% \mathrm{MeOH} / \mathrm{CH}_{2} \mathrm{Cl}_{2}\right)$ to afford the title compound 1 as a purple oil $(6.0 \mathrm{mg}, 74 \%)$ : ${ }^{1} \mathrm{H}$ NMR $\left(\mathrm{CDCl}_{3}, 500 \mathrm{MHz}\right) \delta 5.13(\mathrm{~m}, 1 \mathrm{H}), 4.62(\mathrm{dd}, 1 \mathrm{H}, J=4.5,8.9 \mathrm{~Hz}), 4.53-4.58(\mathrm{~m}, 1 \mathrm{H}), 4.35$ (app t, $1 \mathrm{H}, J=5.0 \mathrm{~Hz}$ ), 4.28 (br s, 2H), 4.05 (app d, $1 \mathrm{H}, J=9.2 \mathrm{~Hz}$ ), 4.00 (s, 3H), 3.82 (dd, $1 \mathrm{H}, J=6.0$, $9.3 \mathrm{~Hz}), 3.70-3.74(\mathrm{~m}, 2 \mathrm{H}), 3.50(\mathrm{dd}, 1 \mathrm{H}, J=5.5,12.3 \mathrm{~Hz}) ;{ }^{13} \mathrm{C} \mathrm{NMR}\left(\mathrm{CDCl}_{3}, 125 \mathrm{MHz}\right) \delta$ 182.3, 178.5, 157.2, 156.8, 153.9, 124.6, 120.7, 82.9, 74.6, 74.1, 60.7, 56.4, 45.1, 31.5, 29.3, 28.9, 22.3, 13.4, 7.5; IR (KBr) $v_{\max } 3450,3354,3205,2915,1647,1609 \mathrm{~cm}^{-1}$; HRMS (ESI), $m / z$ calcd for $\mathrm{C}_{15} \mathrm{H}_{17} \mathrm{~N}_{3} \mathrm{O}_{9} \mathrm{Na}$ : 342.1060; found: 342.1057 . 


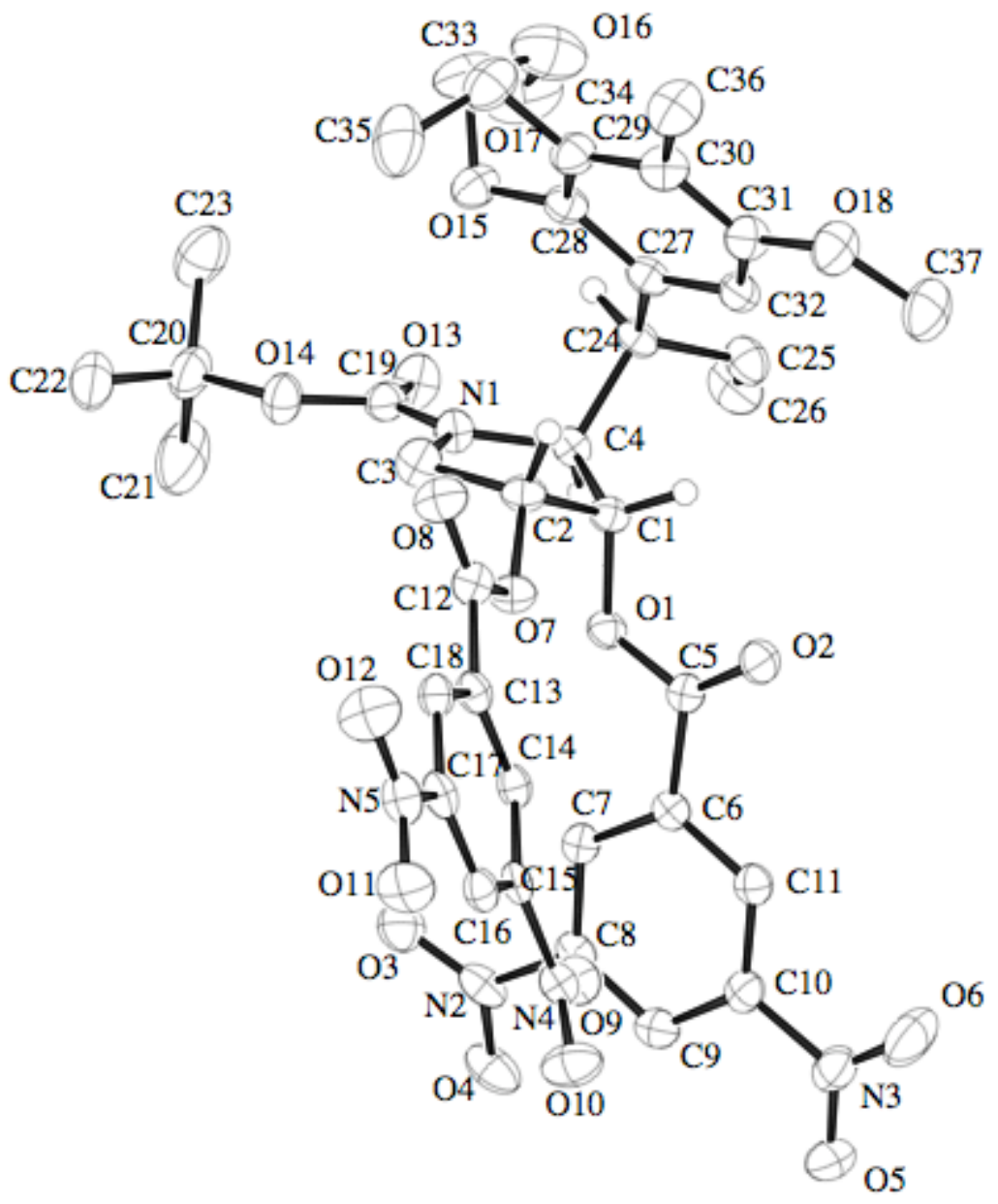

ORTEP Structure of $\mathbf{3 7}$ 